\title{
DOES FINANCIAL REFORM RAISE OR REDUCE SAVINGS?
}

\author{
By \\ Oriana Bandiera \\ (Boston College) \\ Gerard Caprio Jr. \\ (World Bank) \\ Patrick Honohan \\ (World Bank and CEPR) \\ Fabio Schiantarelli \\ (Boston College)
}

\begin{abstract}
We would like to thank Pierre-Richard Agénor, Craig Burnside, Bruce Hansen, Tullio Jappelli, Peter Pedroni, Deborah Wetzel, Stephen Zeldes, participants in seminars at Boston College and the World Bank, and especially Klaus Schmidt-Hebbel, and Luis Servén for useful suggestions.
\end{abstract}




\title{
DOES FINANCIAL REFORM RAISE OR REDUCE SAVING?
}

\author{
By Oriana Bandiera*, Gerard Caprio Jr.**, Patrick Honohan** and Fabio Schiantarelli* \\ (*Boston College, **World Bank)
}

\begin{abstract}
The effect of financial liberalization on private saving is theoretically ambiguous, not only because the link between interest rate levels and saving is itself ambiguous, but also because financial liberalization is a multi-dimensional and phased process, sometimes involving reversals. Some dimensions, such as increased household access to consumer credit or housing finance, might also work to reduce private savings rather than increasing them. Furthermore, the long-term effect of liberalization on savings may differ substantially from the impact effect.
\end{abstract}

Using Principal Components, we construct a 25-year time series index of financial liberalization for each of eight developing countries: Chile, Ghana, Indonesia, Korea, Malaysia, Mexico, Turkey and Zimbabwe. This is employed in an econometric analysis of private saving in these countries.

We find that the pattern of effects differs across countries. In summary, liberalization appears to have had a significant positive direct effect on saving in Ghana and Turkey, and a negative effect in Korea and Mexico. No clear effect is discernible in the other countries. There is no evidence of significant, positive and sizeable interest rate effects.

For the present, our results must be taken as an indication that there is no firm evidence that financial liberalization will increase saving. Indeed, under some circumstances, liberalization has been associated with a fall in saving. All in all, it would be unwise to rely on an increase in private savings as the channel through which financial liberalization can be expected to increase growth. 


\section{Introduction}

A wave of liberalization of financial markets has swept over much of the developing world, especially since the mid-1980s. This liberalization has been characterized by greater scope being granted to market forces in determining interest rates and in allocating credit (Caprio, Atiyas and Hanson 1994). Although this has occurred under the pressure of increased globalization of financial markets, and following the example of many industrial countries, there has been an expectation that financial liberalization would help economic development. In particular, the early literature on financial repression, following McKinnon (1973) and Shaw (1973), stressed the potential role of higher interest rates in mobilizing savings that could be put to productive use.

But it is far from clear that financial liberalization actually does increase private savings. One obvious and important consideration is that the effect of interest rates on savings is itself ambiguous, as the income effect might offset substitution effects. In addition, one must recognize that financial liberalization involves more than just a change in interest rates. Other dimensions of financial liberalization, such as increased household access to consumer credit or housing finance, might also work to reduce private savings rather than increasing them (Muellbauer and Murphy, 1990, Jappelli and Pagano, 1994). ${ }^{1}$ Furthermore, the long-term effect of liberalization on savings may differ substantially from the impact effect. Lastly, financial liberalization is a process rather than a one-shot event.

The purpose of this paper is to provide an empirical examination of the total effect of the financial reform on aggregate private savings based on eight case studies: Chile, Ghana, Indonesia, Korea, Malaysia, Mexico, Turkey and Zimbabwe. These countries have all significantly liberalized their financial sector policies, but they differ in the nature and phasing of financial liberalization, in other aspects of their policy reform program, and in the macroeconomic context in which liberalization took place. This variety allows us to explore the degree to which the savings response differs from country to country, as well as to test whether the response is a common one.

1 There is also the view, stressed in the neo-structuralist contributions of Taylor (1983) and Van Wijnbergen (1982) that the effect of reduced taxation on formal financial intermediaries might actually reduce the flow of credit to the private sector to the extent that reserve requirements captured funds for the government that had been substituted away from the curb market. 
Financial reform typically comprises several key phases, often separated by several years. Reform measures are introduced in a number of different dimensions: interest rates, credit allocation, bank ownership, prudential regulation, security markets and openness of the capital account. There have been frequent debates as to the best sequencing of these various elements. In practice, reform has not been a monotonic process: in some cases there have been setbacks involving temporary policy reversals.

A thorough quantitative assessment of the impact of such a process must take account of its gradual and reversible nature. Based on an analysis of the historical evolution in each case we have identified the timing of major moves on eight different dimensions towards a more liberalized system. Using the principal components of the resulting matrices of zero-one variables (ones correspond to the years after a particular reform is introduced) we obtain a continuous financial liberalization index for each of our countries. Our data extends over a quarter of a century, a period long enough to allow us to model the dynamic response to liberalization in each country separately.

Visual inspection of the time series of the main relevant variables - the financial liberalization index, the real interest rate, monetary depth (either M2 or total credit to the private sector expressed as a percentage of GNDI) and the private savings ratio - reveals little evidence of a clear-cut relationship between saving and liberalization.

We estimate an econometric relationship expressing the private saving ratio as a function of the real interest rate and the index of financial liberalization, along with income, inflation and the savings of the public sector. In addition to directly measuring the contribution of liberalization to the volume of aggregate savings, our procedure improves on earlier estimates of the saving-interest relation, which omitted any role for financial sector liberalization other than the real interest rate channel.

Although they cannot be solved-out for a net effect on the level of savings, Euler equations can be helpful in detecting the extent of credit rationing. In this spirit we also assess the impact of financial reform on the extent of liquidity constraints by estimating an augmented Euler equation for consumption, in which it is assumed (in an extension of the model of Campbell and Mankiw, 
$1989,1991)$ that the fraction of the consumers are liquidity constrained varies with the degree of financial liberalization.

The structure of the paper is as follows. Section II describes the main channels through which financial liberalization may affect savings and briefly reviews the relevant empirical literature. Section III describes the financial reform process as it occurred in each of the eight countries being studied here. This section also explains and graphs our index of financial liberalization and provides summary statistics and bivariate correlations with financial depth and savings. Sections IV and V present the econometric results based on the saving function and on the augmented Euler equation for consumption, respectively. Section VI concludes.

\section{Financial Liberalization and Savings: Theoretical Background and Review of the Empirical Evidence}

Although financial liberalization can enhance the efficiency with which saved resources are channeled into productive use, the effect on the quantity of savings is theoretically ambiguous. ${ }^{2}$

The mechanisms at work here include both long-term and short-term effects. Once it has settled down, a competitive liberalized financial system will typically be characterized by improved savings opportunities, including higher deposit interest rates, a wider range of savings media with improved risk-return characteristics, and in many cases more banks and bank branches, as well as other financial intermediaries. Bank lending rates will typically be higher for those borrowers who had privileged access in the restricted regime, but access to borrowing should be wider. These long-term effects of liberalization on aggregate private saving will be felt through changes in rates of return and in the degree of credit restrictions. Moreover, if financial liberalization also has a

2 It should be stressed at the outset that our evidence is based chiefly on national accounts definitions of saving. These need to be distinguished from intermediated saving or from capital flows. Dornbusch and Reynoso (1989) observe that capital flight through mis-invoicing of trade serves to conceal saving that is being hidden abroad: an apparent increase in saving may really be a reduction in capital flight. Furthermore, they note that, as durable goods purchases are usually treated as consumption in the data, a shift from these to accumulation of financial assets tends to be misleadingly recorded as saving. 
favorable effect on the allocation of resources this will generate increases in income that will, in turn, increase savings. ${ }^{3}$

The process of financial liberalization also unleashes a series of short run effects. Not only can the process of domestic portfolio adjustment lead to transitory changes in the volume of domestic saving, but (especially when combined with liberalization of the foreign exchange market) it may also induce large capital inflows, largely but not exclusively attributable to a return flow of past flight capital. If not sterilized, such inflows can result in a credit boom leading to real income surges, which in turn have a direct, but transitory, effect on the volume of saving. Modeling of the effect of financial liberalization on saving needs to take account of these short run effects, as well as the long-run effect. It is also important to recognize that some of the overall effects can come through the effect of income on saving.

\section{II.1 Steady State Effects}

If financial liberalization improves the rate of return for savers, then knowledge of the interest elasticity of saving can help predict the long-term impact of liberalization on saving. However, because of the wealth and current income effects that will generally be present, there is no presumption as to the direction of the aggregate saving response to an exogenous interest rate change. Despite many studies, this remains an empirically controversial area - partly because of a surprising shortage of reliable and comparable cross-country data on retail interest rates. Recent reviews by Balassa (1990), Srinivasan (1993), and Fry (1995) conclude that more studies have found a positive interest elasticity of savings than a negative one, but the coefficients have generally been small and often insignificant. ${ }^{4}$

3 It should be noted that increased household borrowing may not all go to consumption or housing. A relaxation of borrowing constraints could promote human capital formation, though this will normally be measured as consumption in the National Accounts.

${ }^{4}$ The effect of interest rates on saving could be non-linear, perhaps involving threshold effects. Reynoso (1989) presents some evidence that the response of savings to the interest rate may be represented by a parabola, with savings increasing most significantly when interest rates go from sharply negative to just below zero, then leveling off, and finally declining as real interest rates become very large and positive, in which case they may reflect political uncertainty, peso-effects, bank insolvency, and the like. Interestingly, Levine (1994) finds that the greatest improvement in growth comes from eliminating significantly negative real interest rates, with small gains to further increases. 
Possibly of greater importance for aggregate saving may be the availability of a variety of alternative non-financial assets, the return on which may not be captured by deposit interest rates. While the use of real interest rates implicitly acknowledges that goods inventories are an alternative to financial assets, in principle it would be very useful to take explicit account of alternative investment opportunities, notably the rate of return on owner-occupied housing and other real estate investment. Many developing countries have experienced property booms, and household saving may have been very sensitive to the after-tax rate of return on investment in real estate (see for example, Koskela and Virén, 1994). Unfortunately, in most cases data on such rates of return are not available for developing countries.

Published interest rates may not reflect capital market realities if households and small enterprises are constrained from borrowing what they would wish because of financial repression or for other reasons. To the extent that liberalization reduces these borrowing constraints, saving ratios could be lowered (Jappelli and Pagano (1989), (1994)). There are two mechanisms at work here. First, when the borrowing constraint binds, it induces the individual to consume less. Second, even when the constraints are not binding in the current period, the expectation that they may bind in the future reduces today's consumption.

A very large literature, in response to Hall's (1978) original contribution, has attempted to gauge the importance of borrowing constraints by inferring that any dependence of the change in consumption on income might reflect the inability of households to smooth the intertemporal pattern of their consumption through borrowing (see for instance, Campbell and Mankiw, 1989, 1991; Zeldes, 1989). ${ }^{5}$ The developing country literature here generally confirms the importance of such dependence - with some indication that it has been higher for developing countries (see for instance, Rossi, 1988, Haque and Montiel, 1989, Corbo and Schmidt-Hebbel, 1991).

\section{II.2 Transitional effects of liberalization}

The impact effect of financial liberalization on saving could be larger than the sustained long-term effect. This is because households will be able to revise target precautionary balances, allowing

\footnotetext{
5 The household's inability to borrow at wholesale market interest rates may be a rationing phenomenon, or it may reflect a large wedge between retail deposit and borrowing rates (e.g. money-lender rates). A lower wedge would reduce saving, as King (1986) found for the UK. See also Alessie, Devereux, and Weber (1993) for an analysis of the effects of abolition of credit controls on the demand for cars in the U.K.
} 
for example some middle-aged households that had hitherto been constrained from life-cycle borrowing to consume at a higher rate than they would have over a full-lifetime of unconstrained access to borrowing. These transitional effects suggest that aggregate household saving could dip below its steady state level, and that a surge in consumption may be observed (Muellbauer, 1994). Moreover, as noted above, financial liberalization has been accompanied by real estate booms in some countries; the resulting increase in real wealth also may have a temporarily negative impact on saving. ${ }^{6}$

The large capital inflows that have been associated with recent liberalizations have also had complex short-term macroeconomic consequences. Liberalization of the domestic financial system has typically been only one element of a package of reforms that have been associated with these inflows, and the inflows have proved to be easily reversible. The impact on saving comes through the associated changes in availability and cost of credit, revised expectations of income growth, and increases in financial wealth, especially due to upward movements in property prices. All this may lead to consumption booms and to a fall in the saving rate.

\section{II.3 Quantifying the effects of financial liberalization on saving}

Most empirical examinations of the effects of financial liberalization or, more generally, of financial development on saving have involved adding one or more variables to established econometric specifications either of saving or of the rate of change in consumption. The simplest specifications identify pre- and post- liberalization periods with a dummy variable (an early example is de Melo and Tybout, 1986, for Uruguay); an alternative is to specify a linear trend reflecting gradual liberalization (Muellbauer and Murphy, 1993 for the UK).

Others have employed such proxy variables as the volume of consumer credit (e.g. Jappelli and Pagano 1989, 1994). Ostry and Levy (1995) used this variable both on its own and in interaction with an interest rate, and concluded that liberalization had not only lowered saving in France, but

\footnotetext{
${ }^{6}$ Financial liberalization could affect the value of human and non-human wealth in a variety of ways. An increase in the value of non-human wealth will normally, ceteris paribus, reduce saving as consumption out of income can now be permanently higher. However, it is hard to isolate such wealth effects on saving of financial liberalization, not only because of the difficulty of measuring human and nonhuman wealth, but also because other reforms affecting wealth are usually being undertaken at the same time.
} 
had transformed a negative association between saving and interest rates into a positive one (cf. Bayoumi, 1993 for the UK). An easing of credit market conditions facing households was also detected for the 1980s in Scandinavian countries by Koskela et al. (1992), and Lehmussaari (1990). Here the effect on savings came indirectly through the impact of increased housing finance on house prices.

In their 30-country study, Jappelli and Pagano (1994) also found another type of credit availability variable to be highly significant, namely the normal loan-to-value ratio obtainable from mortgage finance institutions: a 15 percentage point increase in the loan-to-value ratio reducing the national savings rate by 2.6 percentage points. This substantial effect may not be entirely housing-related, as the variable may be capturing movements in wider credit availability.

Other proxy measures of the prevalence of credit constraints that have been used include the percentage of home-owners in certain age-groups, the interest rate wedge on consumer and mortgage loans (Jappelli and Pagano, 1989), and the rate of consumer credit delinquencies (Carroll, 1992). Confirming the evidence for industrial countries, Vaidyanathan (1993) shows that international variations in the sensitivity of consumption to income are positively related to financial depth (measured by the ratio of M2 to GDP), suggesting again the importance of liquidity constraints.

More directly, Miles (1992) estimated that 80 per cent of the total amount of home equity withdrawn by UK households each year in the 1980s was consumed (rather than involving just a portfolio shift), accounting for essentially all of the collapse in the UK personal savings ratio from 12 per cent to less than 5 per cent.

The existence of well-functioning stock markets could also be a factor influencing saving by offering an improved risk-return frontier while retaining liquidity. But again, the predicted impact on aggregate saving is theoretically ambiguous and recent empirical evidence suggests that funds 
attracted to liquid stock markets in developing countries come mainly as a switch from other assets $^{7}$

\section{Financial Reform: Measurement and Effects}

\section{III.1 Financial repression and the process of reform}

The multifaceted nature of financial reform -- involving deregulation, liberalization, globalization, privatization -- complicates the measurement of its effects. In addition, the reforms undertaken in each country have reflected the perceived problems of the pre-reform environment. Prior to reform, most countries experienced a period of mild or severe financial repression: intervention by governments in allocating and pricing credit, controlling what banks and other intermediaries could do, using intermediaries as tax collection devices, and often limiting competition, in particular from foreign institutions. These interventions varied by country, and in some countries included government ownership of banks as a very direct way of influencing how they did business. ${ }^{8}$

In developing countries, intervention in the financial sector went considerably further than the regulation of interest rates and of credit expansion that characterized industrial country policy. In some countries banks were required to hold as much as one-half or more of their liabilities in the form of reserve or liquid assets (often deposits at the central bank) and another large part of the portfolio was dominated by directed credit. Although the latter might have been structured so as to leave significant discretion to the banks for credit assessment and monitoring (as in Japan), in practice in many cases little power or responsibility was left to the banks. ${ }^{9}$ In such cases, with most of their balance sheet effectively out of their own control, banks invested little in credit assessment, monitoring, or asset-liability skills, and in the extreme cases -- formerly socialist

${ }^{7}$ Levine and Zervos, 1996; see also Bonser-Neal and Dewenter, 1996. This conclusion was drawn from the insignificance of indicators of stock market development in cross-section regressions where the dependent variable was the ratio of private saving to GDP.

8 In addition to concerns about an inherent instability of finance, these interventions were often rationalized by a view that finance was not decisive for growth unless harnessed by a benevolent planner. Levine (1997) discusses some of the historical context and developments of attitudes about the financial system. and Caprio, Atiyas, and Hanson (1994) describe financial reforms in Chile, Malaysia, Indonesia, Korea, Turkey, and New Zealand. See also Caprio and Klingebiel (1996).

${ }^{9}$ In some cases, the small size of the economy meant that a government requirement to provide financial support for a sector such as steel-making meant in practice lending to a single steel company, with the result that the banks viewed the risk as belonging to the authorities. 
economies -- the result was a low skill base in finance and little of the infrastructure that supports market-based financial intermediaries. ${ }^{10}$

Beginning in many countries in the 1970s and accelerating subsequently, governments began to reconsider more direct interventions, and financial reform programs have included attempts to reduce or re-direct the government's role, most noticeably in the area of pricing and directing credit. The path of reforms often was influenced both by government views, initial conditions, and political pressures for reform. For example in Chile, real interest rates had been negative for decades prior to the removal of controls in 1974, and this de-control was quite sudden. In contrast, following mild repression in the 1960s, Malaysian authorities in early 1973 -- like their Japanese counterparts much later -- began deregulating some longer term interest deposit rates but let several years pass before all controls were removed. A very gradual process also characterized the Korean experience. At times, the process was rather bumpy with re-imposition of controls after an initial bout of liberalization, as in Chile and Malaysia. Often the re-imposition of controls was a consequence of a severe banking crisis that developed in an unstable macro context, characterized by large capital inflows, and excessive risk taking in the absence of effective prudential regulation, as in Chile in the early 1980s.

Reforms in general include two parts: outright de-regulation, limiting the government's direct intervention, and putting in its place a system of prudential regulation aimed at ensuring the safety and soundness of banking. In addition there is an institution-building component. The latter likely is a key component of the reform process: during periods of substantial intervention, especially where most risk is born by government, the demand for financial infrastructure -- accounting, auditing, legal systems, and other finance-related skills -- is quite limited. When this intervention is lessened, and if the incentive structure is right, intermediaries start devoting more resources to risk and credit analysis, for example, and spend more to upgrade the quality of their staff.

\section{III.2 Measuring financial reform}

10 See Caprio and Claessens (1997) for a discussion of initial conditions in reforming financial systems. They argue that long periods of financial repression greatly weakened the skills, incentives, and infrastructure in finance and therefore complicated the reform process. 
The ideal index of financial reform would attempt to measure both the de-regulatory and the institution building aspects of the process. Unfortunately, short of using outcome measures such as the development of markets as a proxy -- an approach leading in the present context to unacceptable endogeneity difficulties -- it seems impossible at present to find useful measures of institutional development. For these reasons we have chosen to build our index of reform from explicit policy changes which, though not wholly independent of wider economic conditions, should be less subject to endogeneity problems.

Our index thus summarizes exogenous changes in interest rate regulation, reserve requirements, directed credit, bank ownership (moves toward privatization), liberalization of securities markets, prudential regulation, and international financial liberalization. Based on an analysis of the historical evolution in each case we have identified the timing of major moves towards, and sometimes away from, a more liberalized system under each of these headings (Appendix 1 gives the details). This yields a matrix of zero-one variables for each country. Rather than attempting to use all of these variables in the econometrics -- that would use up too many of the available degrees of freedom -- we have constructed for each country the principal components of the matrix. We use the first principal component as our main liberalization index in the regressions of Section IV below. (As an alternative, we also experiment below with a weighted average of the more important principal components, using as weights the fraction of the total standard deviation explained by each component.) In all cases, a higher value of the index in a given year captures an overall more market oriented regime. ${ }^{11}$

The resulting index is shown in Figures 1-8, with data on financial depth (M2 or total credit to the private sector as a percentage of Gross National Disposable Income, GNDI), real interest rates, and the private saving rate (measured as a share of GNDI). We have used a definition of the private saving rate, both unadjusted and adjusted for capital losses due to inflation on domestic assets denominated in local currency. For example in Figure 1a, the index (both versions) captures the partial reversal of reforms in Chile resulting from the twin banking and debt crises of 1982. ${ }^{12}$

${ }^{11}$ See also Demetriades and Luintel (1997) for an application to India of the principal components approach to aggregating the information contained in a combination of policy changes and outcome variables.

12 The Chilean reforms had begun in 1974 with the freeing of interest rates and the beginning of the easing of reserve requirements, and continued in the mid- and late-1970s with bank privatization 
Likewise, Figure 5a clearly charts the fact that de-control was initially short-lived in Malaysia (see Figure 5a), in part because banks were observed to be slow to reduce rates as their cost of funds declined, but also because a moderately severe banking crisis led Malaysian authorities to reimpose interest rate controls for several years in the mid-1980s. ${ }^{13}$

Significant but different reforms were introduced in all of the countries under review. As seen in the data for Chile and Malaysia, reform can see significant reversals, and more generally is not a linear process, but proceeds in fits and starts.

\section{III.3 Visual evidence on savings and reform}

The figures provide no visual evidence of a clear positive association between either index (or real interest rates) and private saving for most countries. This is also confirmed by the bivariate correlation coefficient between saving and the index (contemporaneous or lagged) reported in Table 1 , which is positive and significant only for Turkey and Korea. For some periods and in some of the countries there appears to be a negative relationship between saving and the index. For instance, saving plummets in Chile (Figure 1a and 1d) with the onset of reform -- perhaps reflecting the easing of credit constraints -- then recovers gradually until a more significant increase starting in 1985, associated in part with the introduction of a fully funded pension system. In Mexico (Figures 6a and 6d), we observe a protracted decline in the savings since reforms began. ${ }^{14}$ A lack of correlation between the index of financial reform and savings is evident in the cases of Ghana (Figures 2a and 2d) and Zimbabwe (Figures 8a and 8d), where savings first rose then fell, while the index was registering continuing gains. ${ }^{15}$ In Malaysia, savings did rise in the 1970s as reforms began, but then leveled off and fell back to their original level subsequently. In

and the raising of ceilings on foreign borrowing. After the reversals of 1982, liberalization resumed in 1986.

13 Caprio, Atiyas, and Hanson (1994) describe financial reforms in Chile, Malaysia, Indonesia, Korea, Turkey, and New Zealand. See also Caprio and Klingebiel (1996, 1996a) for a further discussion of the Malaysian experience.

${ }^{14}$ The sharp drop in the adjusted series in 1988 is due to a large increase in the measured stock of debt to which the adjustment applies in that year.

15 Albeit with continued negative interest rates. The persistence of negative real interest rates, notably in the cases of Ghana and Zimbabwe, after the onset of reform measures calls into question how real reforms have been. Even though interest rates were deregulated, in some countries they continue to be controlled by a cartel of banks, often at the informal behest of the authorities. 
contrast, there is a clearer positive association between the index and saving in Korea (Figures 4a and 4d), particularly until the late 1980s, Turkey (Figures 7a and 7d), and to a lesser extent Indonesia, where, however, part of the increase in savings occurred before domestic financial reforms began ( see Figures 3a and 3d).

It is noteworthy that the figures and bivariate correlation suggest a closer association between the behavior of the index and measures of financial depth for a majority of the countries. The exceptions are Turkey, Ghana and Zimbabwe. There also appears to be a generally positive association between our index and real interest rates, which is statistically significant in half of the countries.

\section{Econometric Evidence: Savings Functions}

We begin by estimating the long run and short run relationship between savings and its determinants separately for each country over the period $1970-1994 .^{16}$. In the basic specification, the (unadjusted) private saving rate $s_{t} / y_{t}$ is modeled as a function of the natural log of real per capita GNDI $\ln y_{t}$, the real interest rate $r_{t}$, our index of financial liberalization $f l i_{t}$, the inflation rate $?{ }_{t}$, and the government saving rate, $\operatorname{govs}_{t} .{ }^{17}$ The choice of variables included in the equation is limited partly by series availability and partly by the length of the sample period. In particular we would like to have included a satisfactory proxy for non-human wealth, but available ones, such as the stock of high-powered money or government debt, are more likely to be misleading than helpful.

We have tested the order of integration of the variables both country by country, using the ADF test, and by panel, using the Im, Pesaran and Shin (1996) test. The results of the tests suggest that we cannot reject the hypothesis that $s_{t} / y_{t}, \ln y_{t}, f l i_{t}$, and $g o v s_{t}$ are integrated of order one (see Table 2, Part I for the panel tests; the country by country ADF tests are not reported for reasons of

16 Except for slightly shorter samples for: Indonesia (1971-1994), Korea (1970-1993), and Zimbabwe (1974-1993).

17 Gross national disposable income is used as a proxy for income. The real interest rate is defined as a short term rate (continuously compounded) minus the inflation rate (calculated as the forward log difference). The conclusions reached below are not sensitive to the definition of the real interest rate and of the inflation rate. See the data appendix for further details on variable constructions and on the data sources. 
space). However for some countries there is evidence against the unit root hypothesis for $r_{t}$ and $?{ }_{t}$. For instance, when a trend is included, the hypothesis that $r_{t}$ has a unit root is rejected at the 5\% significance level in Malaysia, Korea and Indonesia. Also, a unit root in ? ${ }_{t}$ is rejected for Malaysia, Indonesia and Turkey. The panel test suggests the rejection of the unit root hypothesis for both variables.

Using the Dickey Fuller (DF) or the Adjusted Dickey Fuller (ADF) tests on the residuals of the cointegrating regressions, country by country, and the critical values calculated as suggested by MacKinnon (1990) to adjust for sample size, we cannot reject the hypothesis of no cointegration between the vector of variables mentioned above (including or excluding the real interest rate and inflation). These cointegration tests must be treated with a healthy dose of caution both because of the low power of such tests against reasonable alternatives and because of the small number of observations available relative to the number of variables. As shown in Table 2, Part II, however, the panel cointegration test proposed by Pedroni (1997a, b), and the Im, Pesaran and Shin test applied to the residuals of the cointegrating vector are consistent with the existence of a cointegrating relationship between $s_{t} y_{t}, \ln y_{t}, f l i_{t}$, and $\operatorname{govs}_{t}$ (or between $s_{t} y_{t}, \ln y_{t}, f l i_{t}$, govs $_{t}, r_{t}$, and ${ }_{t}$, if the troublesome unit root tests on the last two variables are disregarded).

In Table 3 we present two estimates of the cointegrating vector, when $r_{t}$, and ${ }_{t}$ are included. The estimates of Part I are OLS. Since the conventional OLS standard errors are not valid in this context, Part II shows approximate GLS estimates obtained by including the contemporaneous differences of the right hand side variables as additional regressors and allowing for an AR(1) error term. $^{18}$ The main drawback of the Dynamic GLS estimates is the small number of degrees of freedom available, so that it is probably wise to consider both sets of result. Because the estimates of the coefficients of $r_{t}$, and ? ${ }_{t}$ are problematic if those variables are truly stationary, and although their inclusion does not invalidate the consistency for the coefficients (and associated inference) for the other non- stationary variables, we also report (Part III) Dynamic GLS estimates when $r_{t}$, and $?{ }_{t}$ are both excluded.

${ }^{18}$ Ideally one would have wanted to include additional leads and lags of the differences, however the length of our sample precludes us from doing that. Our procedure can be seen as an approximation to the DGLS procedure in Stock and Watson (1993). 
In order to assess also the short run effects of liberalization, Table 4 reports an estimated error correction model for saving. ${ }^{19}$ The reported estimates are OLS; unreported GMM estimates lead to the same conclusions concerning the effect of $f l i_{t}$ and $r_{t}$.

Despite the fact that we have here corrected the omission of other dimensions of financial liberalization, there is -- except for the OLS estimate for Mexico -- no evidence from the countryby-country estimates of a significant distinct positive effect of the real interest rate on savings. In most cases the long run point relationship is negative, and significantly so in the case of Ghana and Indonesia. The evidence based on the time series for individual developing countries confirms, therefore, the general conclusion derived from previous studies using pooled time series-cross country data that it is not possible to pin down a systematic positive effect of increases in the interest rate on savings.

So far as the effect of financial liberalization itself is concerned, the picture is mixed. For Korea and Mexico (and Zimbabwe when $r_{t}$, and ${ }_{t}$ are excluded) the coefficient of the index of financial liberalization is negative and significant in the long run (using the Dynamic GLS estimates). For Korea, there is also evidence of a significant negative short run effect. On the other hand, for Turkey and Ghana (only Turkey, when $r_{t}$, and ? ${ }_{t}$ are excluded) there is evidence of a positive and significant long-run effect. ${ }^{20}$

The estimated impacts of the index on private savings are sizable; for example, the results of Table 3 Part II imply that liberalization in Korea and Mexico has permanently lowered savings by $12 \%$ and $6 \%$ of GNDI respectively. On the other hand we estimate that liberalization has raised the savings rate in Turkey by $13 \%$ and in Ghana by $6 \%$.

So far as the other variables are concerned, the income variable is significant in most cases (both in the long and short run). The sign of the coefficient of the inflation rate differs across countries -

\footnotetext{
$19 r_{t}$ and $\pi_{t}$ are included in the cointegrating vector.

${ }^{20}$ Note that these are also the two countries where $f l i_{t}$ is uncorrelated with private credit, suggesting that borrowing constraints may not have been much eased.
} 
significantly negative in Ghana, Indonesia and Malaysia; significantly positive in Mexico. ${ }^{21}$ Finally, there is evidence that an increase in government savings leads to a decrease in private savings. Actually for Korea, Malaysia and Mexico (and, depending upon the specification, Chile and Zimbabwe) the estimates are consistent with Ricardian equivalence, in that the coefficient of govs $_{t}$ is not significantly different from minus one.

If the coefficients are truly the same across countries, then a more efficient estimate can be obtained by imposing that restriction and estimating the cointegrating vector by the SURE method. The drawback may be that one may be imposing invalid restrictions, because of differences in preferences,institutional settings and nature of the liberalization.

Moreover, the construction of the index does not guarantee comparability of scale across countries. Table 5 shows the results of this approach: the regression of column (1) includes only the levels of the explanatory variables, while the regression of column (2) also included their first difference and an $\mathrm{AR}(1)$ error. (The estimated coefficients on these dynamic terms were not restricted and are not reported.)

These constrained SURE estimates imply that the real interest rate has a significant positive effect and financial liberalization a significant negative effect on saving. However, the likelihood ratio test suggests that the assumed equality of coefficients can be rejected at conventional significance levels, which implies that imposing equality across countries is inappropriate. If that problem can be finessed by taking the constrained estimates to be some form of 'typical' response then we find that combining the interest rate and index effects, the typical financial liberalization would have lowered saving. For instance, using the results in column (2), the predicted long-run effect of an increase in the value of the index by 7 points (equal to its median change between the initial and final year of the sample) accompanied by a simultaneous increase in the interest rate from minus $10 \%$ per annum to plus 5\% (also a "typical" change excluding the inflationary episodes during some of the year in Chile and Ghana), results in a decrease of saving equal to 5.5\% of GNDI.

${ }^{21}$ A variety of effects may be associated with inflation, including the fact that it is positively correlated with the private sector's capital loss on monetary assets, the relative-price confusion effect of Deaton (1977), substitution of consumer durables for financial assets as an inflation hedge, or various forms of uncertainty. 
The general conclusions we have reached concerning the effects of financial liberalization in individual countries are robust to several changes in the specification. For instance, we obtain similar results if we use a weighted average of the first few principal components (with the ratio of the standard deviation relative to the total standard deviation) as an index of financial liberalization. This is equivalent to including the principal components separately and imposing the restriction that their coefficient is proportional to the fraction of the total variance explained by each one of them. We experimented with adjusted private and public saving rates and income to allow for capital gains and losses induced by inflation on assets denominated in local currency (see Table 6 for estimates of the cointegrating vector in this case). We also re-estimated the model by using a "backward" real interest rate, defined as the nominal interest rate minus the inflation rate over the preceding period. We tried adding the dependency ratio to the cointegrating vector; we included an interaction term between the interest rate and the financial liberalization index to allow for the interest rate effect to differ depending upon the degree of liberalization; we used both linear and quadratic interest rate terms to capture the idea that the effect on savings may depend upon the value of the interest rate itself. These additional variables did not have significant coefficients. In all of these cases the general conclusions concerning the effect of the liberalization index and of the interest rate on saving remain unaltered.

\section{Econometric Evidence: Augmented Euler Equations}

The negative impact of financial liberalization on saving found for some countries above suggests that liberalization may have weakened credit or liquidity constraints. Curiously, despite dramatic changes in financial structure worldwide, the Euler equation literature on liquidity constrained consumption has not focussed on time-varying constraints.

Here we start with the Campbell-Mankiw (1989), (1991) approach of estimating an Euler equation augmented by the presence of liquidity constrained consumers, and attempt to estimate variation in the proportion of constrained consumers as liberalization proceeds. Thus, let $\phi$ be the proportion of unconstrained consumers and assume that the remainder consume all their income. If $\phi$ is constant then two standard Euler equations are ${ }^{22}$ :

For constant interest and quadratic utility:

22 Cf. Attanasio and Browning (1995). 


$$
\Delta c_{t}=(1-\phi) \Delta y_{t}^{c}+\phi \varepsilon_{t}
$$

For time-varying interest and CRRA utility:

$$
\Delta \ln c_{t}=\mu \phi+\Delta \ln y_{t}^{c}+\phi \sigma r_{t}+\phi \varepsilon_{t}
$$

where $\mu=-\sigma \ln (1+\delta) . \quad \delta$ is the subjective discount rate, $\sigma$ is the intertemporal elasticity of substitution and $y^{c}$ is the per-capita income of the constrained consumers, assumed to be a constant $^{23}$ fraction $\eta$ of per-capita income in the economy.

If we allow $\phi$ to change through time then (1) and (2) become: ${ }^{24}$

$$
\begin{aligned}
& \Delta c_{t}=\left(1-\phi_{t}\right) \Delta y_{t}-\frac{\Delta \phi_{t}}{\phi_{t-1}}\left(\eta y_{t-1}-c_{t-1}\right)+\xi_{t} \\
& \Delta \ln c_{t}=\left(1-\phi_{t}\right) \Delta \ln y_{t}+\phi_{t} \sigma r_{t}-\frac{\Delta \phi_{t}}{\phi_{t-1}}\left(\ln y_{t-1}-\ln c_{t-1}+\ln \eta\right)+\phi_{t} \mu+\xi_{t}
\end{aligned}
$$

where ? ${ }_{t}=? \phi_{t} ?{ }_{t}$.

Equations (3) and (4) emphasize that the sensitivity of consumption to income varies over time, as the share of liquidity constrained consumers varies. Indeed, the sensitivity of aggregate consumption to current income is due to the fact that some consumers consume their income, and as such is proportional to the relative size of the credit constrained group. The sensitivity of consumption to the interest rate also changes over time in (4). But the main novelty is that the timevariation of $\phi$ introduces additional regressors in (3) and (4). In particular, there is a new term of error-correction type involving lagged consumption and income, whose coefficient is equal to the rate of change in the proportion of unconstrained consumers. This consequence of time varying liquidity constraints seems to have been overlooked in the literature.

\footnotetext{
${ }^{23}$ Assuming $\eta$ constant is necessary to have (3) and (4) below in a tractable form.

${ }^{24}$ To derive (3), define per capita consumption $c_{t}=\left(1-\phi_{t}\right) c_{t}^{u}+\phi_{t} c_{t}^{c}$, where the superscripts $u$ and $c$ denote unconstrained and constrained consumers respectively. Then take first differences to obtain: $\Delta\left(1-\phi_{t}\right) c_{t}^{u}+\Delta \phi_{t} c_{t}^{c}=\left(1-\phi_{t}\right) \Delta c_{t}^{u}+c_{t-1}^{u} \Delta\left(1-\phi_{t}\right)+\phi_{t} \Delta c_{t}^{c}+c_{t-1}^{c} \Delta \phi_{t}$. Substituting the definition of $c_{t-1}$ and using $c_{t}^{c}=\eta y_{t}$, gives (3). The derivation of (4) proceeds along similar lines, using a geometric mean with population weights for average per capita consumption (whereas in the empirical implementation we substitute a simple mean consumption).
} 
The error term in (3) and (4) also depends on $\phi_{t}$ giving rise to a need to seek consistent estimates by IV or GMM techniques. For instance, assume that the set of instruments used, $z_{t-1}$, belongs to the information set available at time $t-1$. If $\phi_{t}$ is also a function of variables known at time $t-1$, then $E\left(z_{t-1} ?_{t}\right)=0$ since the forecast error $\varepsilon_{t}$ is by definition uncorrelated with variables at $t-1$. More precisely:

$$
\begin{aligned}
& E\left(z_{t-1} \xi_{t}\right)=E\left(z_{t-1} \phi_{t} \varepsilon_{t}\right)=E_{z, \pi}\left[E\left(z_{t-1} \phi_{t} \varepsilon_{t} \mid z_{t-1}, \phi_{t}\right)\right]=E\left[z_{t-1} \phi_{t} E\left(\varepsilon_{t} \mid z_{t-1}, \phi_{t}\right)\right]=0 \\
& \text { if } \quad E\left(\varepsilon_{t} \mid z_{t-1}, \phi_{t}\right)=0
\end{aligned}
$$

The last assumption is plausible if financial liberalization measures are actually effective one period after being implemented so that $\phi_{t}$ depends upon the lagged value of the liberalization index.

The final step is to relate $\phi_{t}$ to financial liberalization. We will assume that $\phi_{t}$ is an increasing function of the index of financial liberalization lagged one period, $f i_{t-1}$. In Table 7 we summarize the empirical results for the specification that includes the interest rate, estimated by GMM (past values of the included variables are used as instruments). In the first part of the table we present the estimates of the model under the assumption of a constant ? ? (see equation (2)). For the majority of countries the coefficient of income is significant at conventional levels. This is evidence in favor of the presence of liquidity constraints. In the second part of the table we have adopted a logistic specification for $\phi_{t}$, so that $\phi_{t}=1 /\left(1+\exp \left(-\alpha_{0}-\alpha_{1} f l i_{t-1}\right)\right)$ and we have estimated model (4). If financial liberalization relaxes financial constraints ? ${ }_{1}$ would be positive. For two countries (Ghana and Zimbabwe), we have not succeeded in obtaining convergence. For the remaining six countries, the results, on the whole, show lack of a significant relationship between $\pi_{t}$ and the index. ${ }^{25}$ In the only case, Turkey, in which ${ }_{1}$ is significant at conventional levels, it is indeed positive. However, Turkey was the country in which the saving function results suggested a positive direct effect of liberalization on savings.

\footnotetext{
${ }^{25}$ The basic sense of the results does not change if we allow $\alpha_{0}$ to be different when the growth rate of income is negative, or if we choose a different functional form (such as the Gumbel) for $\phi$.
} 
The Euler equation results suggest that financial liberalization has had little impact on the amount of credit available to consumers through the formal financial sector Alternatively, the inconclusive results may stem from the econometric problem of pinning down what is essentially the coefficient of the product of a non-stationary variable $\left(f l i_{t}\right)$, with a stationary one $\left(\Delta \ln y_{t}\right)$. More generally, one might question the adequacy of the instruments used in estimating the augmented Euler equations.

A further reason for us to expect to find (as we do) a stronger influence of liberalization in our savings equation by comparison with the Euler equation, is that the dependent variable of the former relates to total private saving (business as well as household sectors) while the latter relates in principle only to household sector behavior. Just as it is more sensitive to exogenous shocks (Honohan and Atiyas, 1993), business saving in developing countries may be more influenced by liberalization than household behavior, especially as the latter may be more conditioned by informal finance than by reforms that affect mainly the formal sector.

\section{Conclusions}

Our econometric results confirm the visual impression from the figures, as well as much previous literature, that there is no strong reliable interest rate effect on savings. Only when the data is pooled and one assumes that the long-run coefficients are equal across countries (a restriction that the data rejects) can we find evidence of a significant positive interest rate effect on saving -- and even then the effect is small.

Our index of financial liberalization captures several aspects of reform that are not fully represented by changes in the interest rate, such as the increased availability of a variety of saving media with better risk-return characteristics or the relaxation of borrowing constraints, following financial reform. But here too, the econometric evidence on the impact of reform on saving is very mixed. When savings functions are estimated for each of the countries separately, the long-run effect is found to be significantly negative for two (Korea and Mexico), positive for two (Ghana and Turkey), with no clear effect is discernible in the others. When the long run responses are constrained to be equal, the effect of the financial liberalization index is significantly negative and large enough to offset in these constrained estimates the positive effect of the interest rate increases that have accompanied the reforms. 
Estimation of the augmented Euler equation for consumption confirms previous evidence of excess sensitivity of consumption to income. However, with the exception of Turkey, there is not much evidence that such sensitivity has decreased with financial liberalization, although this may due to the econometric difficulty of obtaining precise estimates of the parameters.

This tentative finding of a negative average value for the effect of liberalization on saving suggests that the negative impact of relaxation of borrowing constraints is the dominant factor. The fact that the estimated effect varies from country to country suggests that the process of financial liberalization may have increased consumers' access to credit in differing degrees from country to country to an extent not fully captured by our index. In this context it would be of interest to try to decompose the effects of the reform package further, but our data here is not rich enough to do that.

Another important distinctive characteristic at the country-level is the macro-management that followed the liberalization. As already mentioned, countries undertaking financial reform are prone to an excessive transitory boom in credit, often linked with a surge in property prices. The degree to which this occurs depends on macroeconomic and monetary policy. Thus contrasting monetary policy may have the effect of contaminating the estimated impact of liberalization per se. Further evidence on the accompanying macroeconomic policies for a larger sample of countries would be needed to resolve this issue.

For the present, our results suggest that, while financial liberalization may sometimes increase private saving, the opposite can also be the case. Considering that government saving can also be adversely affected, ${ }^{26}$ it would be unwise to rely on an increase in savings as the channel through which financial liberalization can be expected to increase growth.

Even if financial liberalization does not increase private saving, it does not follow that the process contracts the volume of funds applied to productive investment. For one thing, liberalization can

${ }^{26}$ As noted earlier, financial liberalization includes reducing below market financing for government, and may also increase expenditures by requiring that subsidies be explicit. However, in addition to longer term gains in revenue due to more rapid growth, in the near bank privatization, at least in the right regulatory environment, can save substantial sums, as in Argentina (Clarke and Cull, 1997). 
increase the inflow of capital, including the return of flight capital (Bartolini and Drazen, 1997). For another, by strengthening market discipline and increasing the autonomy of banks and other financial institutions, the various elements of the reform process can have the effect of eliminating less productive uses of loanable funds. These two potentially important aspects are not considered in the present paper. 


\section{References}

Alessie, R., M.P. Devereux, and G. Weber (1993), "Intertemporal Consumption, Durables and Liquidity Constraints: A Cohort Analysis", European Economic Review, 41(1), 37-60.

Attansio, O. P. and M. Browning (1995), "Consumption over the Life Cycle and Over the Business Cycle," American Economic Review, 85(5), pp 1187-1207.

Balassa, B. (1990), "The Effects of Interest Rates on Savings in Developing Countries", Banca Nazionale del Lavoro Quarterly Review, 172, 101-118.

Bartolini, L. and A. Drazen (1997), "Capital Account Liberalization as a Signal", American Economic Review, 87, 138-55.

Bayoumi, T. (1993), "Financial Deregulation and Household Saving", Economic Journal, 103, 1432-1443.

Blanchard, O.J. (1985), "Debts, Deficits and Finite Horizons", Journal of Political Economy, 93, 1045-1076.

Bonser-Neal, C. and K. Dewenter (1996), "Does Financial Market Development Stimulate Savings? Evidence From Emerging Market Stock Markets", University of Indiana, mimeo.

Browning, M, and A. M. Lusardi (1996), "Household Savings: Micro Theories and Micro Facts," Journal of Economic Literature, vol. 34, pp. 1797-1855, December.

Burnside, C. (1996) "Private Consumption and Public Sector Deficits in Mexico, 1985-1995, The World Bank, mimeo.

Caprio, G. Jr., I. Atiyas and J. Hanson (1994), Financial Reform: Theory and Evidence (Cambridge University Press).

Caprio, G., Jr. and D. Klingebiel (1996), "Bank Insolvency: Bad Luck, Bad Policy or Bad Banking?" Presented to the World Bank Annual Conference on Development Economics.

Caprio, G. and C. Claessens (1997), “The Importance of the Financial System For Development: Implications for Egypt," Distinguished Lecture Series number 6, Egyptian Center for Economic Studies.

Campbell, J. and N.G. Mankiw (1989), "Consumption, Income and Interest Rates: Reinterpreting the Time Series Evidence", in O.J. Blanchard and S. Fischer (eds), NBER Macroeconomic Annual 1989, (Cambridge, MA: MIT Press), 185-216.

Campbell, J. and N.G. Mankiw (1991), "The Response of Consumption to Income: A CrossCountry Investigation", European Economic Review, 35, 715-21.

Carroll, C.D. (1992), "The Buffer-Stock Theory of Saving: Some Macroeconomic Evidence", Brookings Papers on Economic Activity 1992-2, 61-135. 
Corbo, V. and K. Schmidt-Hebbel (1991), "Public Policies and Saving in Developing Countries", Journal of Development Economics, 36, 89-115.

Deaton, A.S. (1977), "Involuntary Saving through Unanticipated Inflation", American Economic Review, 67, 899-910.

Deaton, A.S. (1991), "Savings and Liquidity Constraints", Econometrica, 59, 1221-1248.

Deaton, A.S. (1992), "Household Saving in LDCs: Credit Markets, Insurance and Welfare", Scandinavian Journal of Economics, 94 (2), 253-273.

de Melo, J. and J. Tybout (1986), "The Effects of Financial Liberalization on Savings and Investment in Uruguay", Economic Development and Cultural Change, 34, 561-588.

Demetriades, P. and K. Luintel (1997), “The Direct Cost of Financial Repression: Evidence from India”, Review of Economics and Statistics, 79(2), 311-20.

Dornbusch, R. and A. Reynoso (1989), "Financial Factors in Economic Development", American Economic Review, Papers and Proceedings, 79, 204-209.

Engle, R.F. and B.S. Yoo (1987), "Forecasting and Testing in Cointegrated Systems, Journal of Econometrics, 35, 143-59.

Fry, M.J. (1995), Money, Interest, and Banking in Economic Development, (2nd Edn.) (Baltimore: Johns Hopkins).

Hall, R.E. (1988), "Intertemporal Substitution in Consumption", Journal of Political Economy, 96, 339-357.

Haque, N.U. and P. Montiel (1989), "Consumption in Developing Countries: Tests for Liquidity Constraints and Finite Horizons", Review of Economics and Statistics, 34, 408-415.

Honohan, P. and I. Atiyas (1993), "Intersectoral Financial Flows in Developing Countries" Economic Journal, 103 (418), pp. 666-679.

Im, K.S., M. H. Pesaran and Y. Shin (1995), “Testing for Unit Roots in Heterogeneous Panels”, University of Cambridge, mimeo.

Jappelli, T. and M. Pagano (1989), "Consumption and Capital Market Imperfections: An International Comparison", American Economic Review, 79, 1088-1105.

Jappelli, T. and M. Pagano (1994), "Saving, Growth and Liquidity Constraints", Quarterly Journal of Economics, 109, 83-109.

Koskela, E., H.A. Loikkanen and M. Virén (1992), "House Prices, Household Savings and Financial Market Liberalization in Finland", European Economic Review 36, 549-558. 
Koskela, E. and M. Virén (1994), "Taxation and Household Saving in Open Economies - Evidence from the Nordic Countries", Scandinavian Journal of Economics, 96, 425-441.

Lehmussaari, O.P. (1990), "Deregulation and Consumption Saving Dynamics in the Nordic Countries", IMF Staff Papers, 37, 71-93.

Levine, R. (1997), "Financial Development and Economic Growth", Journal of Economic Literature, 35(2), 688-727.

Levine, R. and S. Zervos (1996), "Stock Markets, Banks and Economic Growth", World Bank Policy Research Working Paper 1690.

McKinnon, R. (1973), Money and Capital in Economic Development, (Washington, D.C. Brookings Institution).

MacKinnon, J.G. (1990), "Critical Values for Cointegration Tests", Economics, University of California at San Diego, Discussion Paper 90-4, January.

Miles, D. (1992), "Housing Markets, Consumption and Financial Liberalization in the Major Economies", European Economic Review, 36, 1093-1135 (with discussion).

Muellbauer, J. (1994), "The Assessment: Consumer Expenditure", Oxford Review of Economic Policy, 10, 1-39.

Muellbauer, J. and A. Murphy (1990), "Is the UK Balance of Payments Sustainable?", Economic Policy, 11, 345-83.

Muellbauer, J. and A. Murphy (1993), "Income Expectations, Wealth and Demography in the Aggregate UK Consumption Function", Paper presented to the HM Treasury Academic Panel. mimeo.

Ostry, J. D. and J. Levy (1995), “Household Savings in France: Stochastic Income and Financial Deregulation”, International Monetary Fund Staff Papers, 4, 375-97.

Pedroni, P. (1997a) "Panel Cointegration: Asymptotic and Finite Sample Properties of Pooled Time Series Tests with an Application to the PPP Hypothesis", Mimeo, University of Indiana.

Pedroni, P. (1997b), “Approximate Critical Values for Cointegration Tests in Heterogeneous Panels with Multiple Regressors", mimeo, University of Indiana.

Reynoso, A. (1989) Essays on the Macroeconomic Effects of Monetary Reform, Price Controls and Financial Repression, MIT Dissertation.

Rossi, N. (1988), "Government Spending, the Real Interest Rate, and the Behavior of Liquidity Constrained Consumers in Developing Countries", IMF Staff Papers, 35, 104-140.

Schmidt-Hebbel, K, S.B. Webb, and G. Corsetti (1992), "Household Saving in Developing Countries: First Cross-Country Evidence", World Bank Economic Review, 6, 529-547. 
Shaw, E.S. (1973), Financial Deepening in Economic Development. (New York: Oxford University Press).

Srinivasan, T.N. (1993), "Saving in the Development Process", in J.H. Gapinski, ed., The Economics of Saving (Dordrecht: Kluwer).

Stock, J. H. and M. W. Watson (1993), “A Simple Estimator of Cointegrating Vectors in Higher Order Integrated Systems”, Econometrica, 61, 783-820.

Taylor, L. (1983), Structuralist Macroeconomics: Applicable Models for the Third World, (New York: Basic Books).

Vaidyanathan (1993), "Consumption, Liquidity Constraints and Economic Development", Journal of Macroeconomics, 15, 591-610.

Van Wijnbergen, S. (1982), "Stagflationary Effects of Monetary Stabilization Policies: A Quantitative Analysis of South Korea", Journal of Development Economics, 10, 133-69.

Zeldes, S.P. (1989), "Consumption and Liquidity Constraints: An Empirical Investigation", Journal of Political Economy, 97, 305-46. 


\section{APPENDIX 1. Building an Index for Financial Liberalization.}

Financial liberalization packages generally consist of a wide range of different measures. As explained in the text we summarize all the information available on the liberalization process by a single index.

One way of building the overall index of financial liberalization is to use principal components methods. The idea is to associate a dummy variable to each reform measure. Its value equals one in the years characterized by the liberalized regime, and zero otherwise. We collect all the dummy variables as columns of a matrix $X$, and then compute the principal components of X. In the text we use two different indexes. One is just the first principal component (i.e. the vector that explains the greater portion of variance). The second one is computed as a weighted average of the more relevant components that explain, cumulatively, $95 \%$ of the total variation of $\mathrm{X}$. We use the fraction of the total standard deviation explained by each component as weights, so that the first principal component is weighted more than the second and so on.

The columns of $X$ representing the timing of the most important liberalization measures and are ordered according to the following scheme:

\section{Domestic Financial Liberalization.}

\section{1.a Interest rates.}

Dummies for the timing of liberalization of interest rates $\left(\operatorname{Dr}_{i}=1\right.$ when interest rates are freed)

\section{1.b Pro-competition measures.}

Includes lowering of entry barriers, permissions to offer new services and other measures intended to foster competition in the financial markets. (Dco=1 when measures are taken)

\section{1.c Reserve requirements.}

Most financial liberalization packages include a reduction in reserve requirements, which increases the funds available for lending. (Dres $=1$ when reserve requirements are reduced)

\section{1.d Directed Credit}

This set of variables includes all the measures aimed to reduce the amount of preferential loans, or loans at a preferential rate, banks are forced to make. (Dpr=1 when directed credit is reduced.)

\section{1.e Banks' ownership}

Dpriv=1 when banks are privatized or government controls are reduced.

\section{1.f Prudential Regulation.}


Typically financial liberalization programs include a strengthening of prudential regulation and supervisory powers of the $C B$. This is relevant in which it can increase the trust in the financial system and hence attract more deposits. (Dreg=1 when prudential regulation measures are in force)

\section{Securities Markets}

These variables capture the measures aimed at deregulating and developing the securities and stock markets ( $\mathrm{Dst}=1$ when markets are deregulated)

\section{International Financial Liberalization.}

Domestic financial liberalization is generally paired with international liberalization both in the capital and in the current account. Here we use the information relative to the capital account and the exchange rate. ( $\mathrm{Df}=1$ when capital movements and/or the exchange rate are liberalized). 


\section{CHILE}

\section{Domestic Financial Liberalization.}

\section{1.a Interest rates.}

1974(may) Interest rates for institutions other than commercial banks, the state bank, and saving and loans are freed.

1974(june) Controls on deposit rates are abolished

1975(may) Controls on lending rates are abolished

1975(oct) Controls are re-imposed on both rates

1976(jan) Controls are removed

1977(sept) Banks are allowed to make contracts using a unit of account anchored to the CPI

1982(dec.) Central bank "suggests" deposit rates

1986(jan) Controls (i.e. suggestions) on interest rates are definitely abolished

\section{1.b Pro-competition measures.}

1975 Entry barriers are lowered.

\section{1.c Reserve requirements.}

1974(oct) Reserve requirements on short term( 1 to 12 months) time deposits are reduced (from $40 \%$ to $8 \%$ )

1975(jul) reserve requirements on demand deposits are reduced (before base rate $=100 \%$ marginal rate $=80 \%$, after uniform rate $=80 \%$ )

1975 (aug)

increased

1976(may)

technical reserve requirements on short term time deposits are

1976

(to $80 \%$, to be fulfilled by a mandatory investment in T-bills)

(may-dec77)

CB pays interest rate on reserves

reserve requirements are reduced on demand deposits (to 59\%), on

1-3m time dep. (to 20\%) and on 3-12m time deposits (to $8 \%$ ).

1978(jan-jul) reserve requirements are reduced on demand deposits ( to 42\%)

1979 reserve requirements are reduced on demand deposits ( to $21 \%$ ), on 1-

(april-dec) $3 \mathrm{~m}$ time deposits ( to $8 \%$ ),

1979(sep) CB stops paying interest on reserves

1980 reserve requirements are reduced on demand deposits ( to 10\%), on 1 -

(jan-dec.) 3m time dep. (to $4 \%$ ) and on 3-12m time deposits (to $4 \%$ ).

\section{1.d Directed Credit \& Credit Ceilings}

$1926 \quad$ credit ceilings are introduced

1974(jan-sept) new, more relaxed ceilings are introduced

1974(oct-dec.) ceilings are completely abolished

1975(jan-jul) ceilings are re-established but banks are allowed to increase their loans by the increment in time deposits over the outstanding amount as of september 1974

1975(aug)-1976(mar) the ceiling is set a the amount of outstanding loans as of jul 75

1976 (april) ceilings are definitely abandoned 


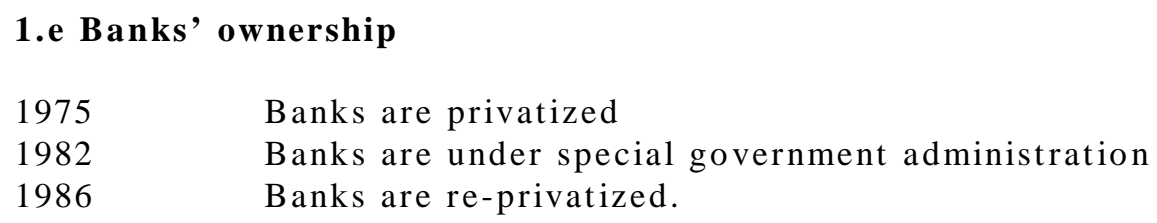

\section{1.f Prudential Regulation.}

1986(nov) New banking law, includes prudential measures and strengthens the supervisory system.

1987 Deposit Insurance Scheme is introduced.

\section{International Financial Liberalization.}

\begin{tabular}{|c|c|}
\hline $1975(\mathrm{jan})$ & $\begin{array}{l}\text { Ceilings on foreign borrowing are reduced (from } 200 \% \text { to } 100 \% \text { of } \\
\text { capital and reserves) }\end{array}$ \\
\hline $1976($ jun $)$ & Ceilings on foreign borrowing are increased (to $150 \%$ ) \\
\hline $1978($ jan $)$ & $\begin{array}{r}\text { Foreign borrowing is authorized for every purpose (before it was } \\
\text { allowed only for financing loans related to foreign trade) }\end{array}$ \\
\hline $1978($ mar $)$ & Ceilings on foreign borrowing are increased (to $160 \%$ ) \\
\hline $1978($ apr $)$ & $\begin{array}{l}\text { Short term foreign borrowing by banks is forbidden. Reserves are } \\
\text { imposed on long-term borrowing (rates are differentiated according to } \\
\text { maturity). Limits on foreign currency loans are imposed (both stock and } \\
\text { flow) }\end{array}$ \\
\hline 1978(dec.) & Ceilings on foreign borrowing are increased (to 180\%) \\
\hline 1979(jun) & Ceilings on foreign borrowing are abolished \\
\hline $1980($ jan $)$ & reserve req. on foreign currency deposits are reduced \\
\hline $1980($ apr $)$ & $\begin{array}{l}\text { limits on foreign currency loans are eliminated. (after this the only } \\
\text { restrictions left on capital movements are the prohibition of short } \\
\text { term(2yrs) foreign loans and reserve req. on loans with maturities } \\
\text { between } 2 \text { yrs and } 51 / 2 y r s \text { ) }\end{array}$ \\
\hline 1984 & Capital movements are restricted. \\
\hline 1991 & Restrictions are reduced again. \\
\hline
\end{tabular}

\section{GHANA}

\section{Domestic Financial Liberalization.}

\section{1.a Interest rates.}

1987 (9) Decontrolled all interest rates.

\section{1.b Pro-competition measures.}

1993(5) Enacted new law to foster competition among commercial banks. Also enacted Home Mortgage Finance Law to support development of housing finance. 


\section{1.d Directed Credit}

1988 (2) Removed almost all credit controls (except agriculture)

1990(11) Removed lending targets for the agricultural sector.

\section{1.e Banks' ownership}

The sector is dominated by State-owned institutions. There have not been changes in this direction.

\section{1.f Prudential Regulation.}

1989(8) Enacted a Banking Law providing for minimum capital and prudential lending guidelines.

\section{Securities Markets}

1986 Introduced weekly foreign exchange auction.

1987 (10) Introduce weekly auctions of T-bills.

1987 (11) Establishment of the Consolidated Discount House.

1990 (11) Stock Exchange Operations Begin.

\section{International Financial Liberalization.}

No reforms in this area. Capital movements are still subject to controls.

\section{INDONESIA}

\section{Domestic Financial Liberalization.}

\section{1.a Interest rates.}

1983 Interest rates on loans and deposits are freed. (Except rates on loans refinanced by $\mathrm{CB}$ )

\section{1.b Pro-competition measures.}

1988 Entry of new banks is allowed. Banks who satisfy the criteria for

(10-12) financial soundness are allowed to open new branches. All banks can issue Cds and are allowed to offer new services.

\section{1.c Reserve requirements.}

1988 Reserve requirements are reduced from $15 \%$ to $2 \%$

\section{1.d Directed Credit}


1983 The role of $C B$ in allocating credit is reduced. The number of categories of credit for which banks would be refinanced by CB is reduced.

1990 Most of the liquidity credit arrangements for priority loans are eliminated.

\section{1.f Prudential Regulation.}

1989 Prudential measures as capital adequacy ratio are introduced.

1991 Prudential measures are reinforced.

1992 New prudential measures are approved and the supervisory power of CB is reinforced.

\section{Securities Markets}

1977 The Stock Exchange opens in its present form but remains virtually inactive until 1989.

1988 New measures to strengthen and deregulate the stock market.

\section{International Financial Liberalization.}

No controls on capital movements and foreign exchange.

\section{KOREA}

\section{Domestic Financial Liberalization.}

\section{1.a Interest rates.}

1984 Financial intermediaries (non-bank) are given discretionary power in determining their lending rate.

1988 Most banks' lending and long term deposits rates are deregulated.

\section{1.b Pro-competition measures.}

1983 Entry barriers are lowered and banks are allowed to introduce new services.

1989 Entry Barriers are lowered again. The establishment of new financial institutions is approved.

\section{1.d Directed Credit}

The share of policy loans is quite high, after peaking at the end of the 70 s. No significant measures have yet been taken to reduce it.

\section{1.e Banks' ownership.}

Although they have been privatized in 1981-3 banks remain heavily controlled by the State. 


\section{1.f Prudential Regulation.}

1991 General Banking Act introduces new prudential measures and imposes supervisory regulations

\section{Securities Markets}

1984 Establishment of the Korea Fund.

1992 The stock market opens for direct purchase by foreigners.

\section{International Financial Liberalization.}

Capital movements and the exchange rate are still heavily regulated. Significant dates are:

$1981 \quad$ Capital movements are less controlled

1989 Foreign Exchange market is established.

NB: Although the bank sector is still quite regulated, non-bank financial intermediaries are not. Financial markets in Korea have become more deregulated essentially because the share of non-bank intermediaries has grown noticeably. To capture this effect we include the series (financial intermediaries' claims to private sector/GDP) in the financial liberalization index.

\section{MALAYSIA}

\section{Domestic Financial Liberalization.}

\section{1.a Interest rates.}

1971

1972

1973

1978

1984

1985 (oct)

1987 (jan)

$1987($ apr $)$

1987 (sep)

1991
Interest Rates on long term (4 or more years) deposits are liberalized.

Rates on deposits with maturity greater than 1 year are freed.

Rates on deposits placed with finance companies are freed.

All interest rates of commercial banks are freed.

New controls are set on the lending rates. Specifically, the Base

Lending Rate (BLR) is introduced. Lending rates offered by every bank and finance company are then anchored to their declared BLR, determined on the basis of the cost of funds taking into account the cost of statutory reserves, liquid assets requirements and overheads.

Controls on deposits rates are reintroduced.

Controls on deposits rates are eliminated.

Interest rates on priority lending are pegged to the BLR

The CB imposes new, and more restrictive, guidelines for the determination of the BLR

The BLR is freed from CB's control. 


\section{1.d Directed Credit}

1975 Priority lending is introduced. CB controls both the quantity and the interest charged on primary borrowers.

1979 CB issues annual priority lending guidelines, still leaving considerable discretion to the banks and without seriously distorting the interest rates.

1991 The number of priority sectors and the required loan amount is reduced.

\section{1.f Prudential Regulation.}

1989

The Banking and Financial Institutions Act extends and strengthens CB's supervisory powers.

\section{Securities Markets}

1973

Discount Rates on T-bills are determined by open tender in the money market.

1989 Measures to move toward a market-based pricing of government $\mathrm{X}$ market.

\section{International Financial Liberalization.}

1973 Exchange rate regulations are relaxed to allow a freer flow of funds to and from Malaysia

1987 New measures to provide investors with greater access to credit.

$\underline{\text { Notes. }}$

(1) In mid-82 Malaysia started a multi-year structural adjustment program.

\section{MEXICO}

\section{Domestic Financial Liberalization.}

\section{1.a Interest rates.}

1988-89 Interest rates are liberalized.

\section{1.b Pro-competition measures.}

New legal framework for banks and non-banks financial intermediaries. The new law promotes competition, allows the introduction of new 
services and establishes prudential measures. Also, favors the development of non-bank financial institutions.

\section{1.c Reserve requirements.}

1989 Reserve requirements are reduced.

\section{1.d Directed Credit}

1988 Elimination of forced lending.

1991 Elimination of the "liquidity coefficient", requiring that $30 \%$ of deposits be invested in T-bills.

1992 Elimination of regulations requiring that banks hold long term government bonds until maturity.

\section{1.e Banks' ownership}

1982

1992

Banks are nationalized. Credit to private sector falls sharply. Banks are privatized.

\section{Securities Markets}

1988-92 During this period measures have been taken to deregulate the securities market and promote its development. Despite recent growth the securities market is still under-developed.

\section{International Financial Liberalization.}

Notes:

1) Mexico started a macro-adjustment program in 1988.

\section{TURKEY}

\section{Domestic Financial Liberalization.}

\section{1.a Interest rates.}

Interest rate ceilings are abolished (except on sight deposits and on preferential lending) 


\section{1.b Pro-competition measures.}

$1980 \quad$ Cds are introduced.

$1981 \quad$ Barriers to entry are lowered.

\section{1.f Prudential Regulation.}

1986 A new banking law becomes effective. The law provides supervisory and prudential measures. A Bank Supervision Unit is created within the Central Bank.

\section{Securities Markets}

1983 The Capital market Board is established. CMB promotes and monitors developments in the securities markets.

1985 Government Securities are auctioned. Their yields are marketdetermined.

1986 The Istanbul Stock Exchange becomes operative.

\section{International Financial Liberalization.}

1984 Foreign Exchange deregulation: residents are allowed to hold foreign currency denominated deposits (FCCDs). Banks are allowed to keep foreign currency abroad and are given some discretionary power in determining the exchange rate.

1985 New restrictions on foreign exchange are introduced.

$1988 \quad$ Foreign Exchange is liberalized.

1989 Capital movements are liberalized.

1990 The Exchange rate is liberalized.

\section{ZIMBAB WE}

\section{Domestic Financial Liberalization.}

\section{1.a Interest rates.}

Restrictions on all interest rates are eliminated.

\section{1.b Pro-competition measures.}

No special measures have been taken in this field and banks have only very recently started to offer new services. Although the number of financial institutions and the range of services offered are impressive by African standards, competition is scarce. Some new institutions have entered the financial market but this has not changed the status quo. 
1.c Reserve requirements.

$1991 \quad$ Reserve Requirements are reduced.

\section{Securities Markets}

1973 The Stock Exchange is created.

1993 The Stock market is opened to foreign investors.

\section{International Liberalization}

1994

The current account and the foreign exchange are liberalized

Notes:

1. The program started in 1991 included measures to reduced the budget deficit, but these have been quite unsuccessful.

2. There has been a minor deregulation in 1988 . 


\section{APPENDIX 2- Variables Definitions and Data Sources.}

$(\mathbf{s} / \mathbf{y})_{\mathbf{t}}=$ private saving rate $=(\text { private savings } / \mathrm{GNDI})_{\mathrm{t}}$

private savings $=$ gross national savings - public sector savings

gross national savings, Source: WB “World Savings Database” Rev. 3.00.

public sector savings $=$ (1) for CHL, KOR, MEX, MYS, TUR - savings of the nonfinancial public sector $(=$ consolidated central government + state and local governments + non financial public enterprises) computed as revenues minus consumption - Source: WB "World Savings Database" Rev. 3.00. (2) for IDN savings of the consolidated central government computed as revenues minus consumption - Source: WB "World Savings Database" Rev. 3.00. (3) for Ghana - savings of the consolidated central government computed as buget surplus plus public investment - Source: Ghana-Quarterly Digest of Statistics (4) for Zimbabwe - savings of the consolidated central government computed as buget surplus plus public investment - Source: World Bank National Accounts + Easterly database.

GNDI: GNP + External Transfers - Source: WB “World Savings Database” Rev. 3.00.

$\mathbf{y}_{\mathbf{t}}=\log$ of real per-capita income $=\ln (\mathrm{GNDI} / \text { population } * \mathrm{defl})_{\mathrm{t}}$

population: Source WB BESD database.

$\pi_{\mathbf{t}}=$ inflation rate $=\Delta \ln \left(\operatorname{defl}_{\mathrm{t}+1}\right)$.

defl: implicit consumption price deflator - year average- Source: WB "World Savings Database" Rev. 3.00.

$\mathbf{r}_{\mathbf{t}}=$ real interest rate $=(1)$ for IDN, KOR, MYS $r_{t}=\ln \left(1+i_{t}^{a}\right)-\Delta \ln \left(\operatorname{defl}_{t+1}\right)$ (2) for CHL, GHA, MEX, TUR, ZWE $\mathrm{r}_{\mathrm{t}}=0.5\left(\ln \left(1+\mathrm{i}_{\mathrm{t}}{ }^{\mathrm{d}}\right)+0.5\left(\ln \left(1+\mathrm{i}_{\mathrm{t}-1}{ }^{\mathrm{d}}\right)\right)-\Delta \ln \left(\operatorname{defl}_{\mathrm{t}+1}\right)\right)$.

$i^{a}=$ nominal interest rate $=$ short term deposit rate, year average - Source $:$ Central Banks Bulletins.

$i^{d}=$ nominal interest rate $=$ short term deposit rate, December value - Source $:$ Central Banks Bulletins.

$\mathbf{f l i}_{\mathbf{t}}=$ index of financial liberalisation - Source: our calculations

govs $_{\mathbf{t}}=$ public sector saving rate (relative to GNDI) - Source: WB "World Savings Database" Rev. 3.00. 
$(\mathbf{s} / \mathbf{y})_{\mathbf{t}}{ }^{\mathrm{a}}=$ private savings ratio adjusted for domestic capital gains - Source: WB "World Savings Database" Rev. 3.00.

$\mathbf{y}_{\mathbf{t}} \mathbf{a}^{\mathbf{a}}=$ GNDI adjusted for domestic capital gains - Source: WB "World Savings Database"

Rev. $3.00+$ our calculations

govs $_{\mathbf{t}}{ }^{\mathrm{a}}=$ public sector saving rate adjusted for domestic capital gains - Source: WB "World Savings Database" Rev. 3.00. 


\section{TABLE 1: CORRELATION COEFFICIENTS}

M2/GNDI $\begin{gathered}\text { Private } \\ \text { Credit/GNDI }\end{gathered} \quad \mathbf{r}_{\mathrm{t}} \quad(\mathrm{s} / \mathbf{y})_{\mathrm{t}}$

\section{CHILE}

$\begin{array}{ccccc}\mathrm{fli}_{\mathrm{t}} & 0.614 & 0.74 & 0.767 & 0.153 \\ & (3.72) & (5.31) & (5.74) & (0.74) \\ \mathrm{fli}_{\mathrm{t}-\mathrm{l}} & 0.671 & 0.800 & 0.806 & 0.141 \\ & (4.23) & (6.25) & (6.32) & (0.70) \\ \mathrm{fli}_{\mathrm{t}-2} & 0.761 & 0.844 & 0.73 & 0.173 \\ & (5.36) & (7.23) & (5.01) & (0.82)\end{array}$

\section{GHANA}

$\begin{array}{ccccc}\mathrm{fli}_{\mathrm{t}} & -0.35 & -0.07 & 0.44 & -0.29 \\ & (-1.79) & (-0.34) & (2.39) & (-1.48) \\ \mathrm{fli}_{\mathrm{t}-1} & -0.27 & -0.0006 & 0.4 & -0.26 \\ & (-1.33) & (-0.03) & (2.10) & (-1.3) \\ \mathrm{fli}_{\mathrm{t}-2} & -0.24 & 0.10 & 0.41 & -0.29 \\ & (-1.16) & (0.50) & (2.12) & (-1.13)\end{array}$

\section{INDONESI}

A

$\begin{array}{cc}\mathrm{fli}_{\mathrm{t}} & 0.94 \\ & (13.80) \\ \mathrm{fli}_{\mathrm{t}-1} & 0.91 \\ & (10.60) \\ \mathrm{fli}_{\mathrm{t}-2} & 0.87 \\ & (7.98)\end{array}$

0.95
$(13.92)$
0.93
$(11.38)$
0.88
$(8.68)$

0.52

$(2.91)$

0.42

(2.18)

0.35

(1.70)

0.37

(1.89)

0.35

(1.71)

0.377

(1.78)

KOREA

$\begin{array}{ccccc}\mathrm{fli}_{\mathrm{t}} & 0.878 & 0.905 & 0.311 & 0.739 \\ & (8.60) & (10.03) & (1.54) & (5.16) \\ \mathrm{fli}_{\mathrm{t}-1} & 0.86 & 0.883 & 0.300 & 0.721 \\ & (7.82) & (8.78) & (1.47) & (4.79) \\ \mathrm{fli}_{\mathrm{t}-2} & 0.83 & 0.854 & 0.282 & 0.748 \\ & (6.72) & (7.50) & (1.33) & (5.09)\end{array}$

\section{MALAYSI}

A

$\begin{array}{ccccc}\mathrm{fli}_{\mathrm{t}} & 0.75 & 0.76 & 0.34 & -0.22 \\ & (5.46) & (5.69) & (1.71) & (-1.08) \\ \mathrm{fli}_{\mathrm{t}-1} & 0.77 & 0.78 & 0.58 & -0.39 \\ & (5.79) & (5.97) & (3.43) & (-1.99) \\ \mathrm{fli}_{\mathrm{t}-2} & 0.79 & 0.81 & 0.71 & -0.57\end{array}$



(6.04)
(6.33)
(4.59)
(-3.17)

\section{MEXICO}

$\begin{array}{ccccc}\mathrm{fli}_{\mathrm{t}} & 0.20 & 0.82 & 0.36 & -0.59 \\ & (0.99) & (8.91) & (1.79) & (-3.47) \\ \mathrm{fli}_{\mathrm{t}-1} & 0.22 & 0.87 & 0.31 & -0.59 \\ & (1.13) & (8.34) & (1.60) & (-3.5) \\ \mathrm{fli}_{\mathrm{t}-2} & 0.22 & 0.69 & 0.3 & -0.59 \\ & (1.07) & (6.81) & (1.42) & (3.39)\end{array}$

\section{TURKEY}

$\begin{array}{cc}\mathrm{fli}_{\mathrm{t}} & 0.76 \\ & (5.76) \\ \mathrm{fli}_{\mathrm{t}-1} & 0.74 \\ & (5.22) \\ \mathrm{fli}_{-2} & 0.72 \\ & (4.77)\end{array}$

0.004
$(0.019)$
0.003
$(0.02)$
0.04
$(0.24)$

0.30

(1.50)

0.87

0.28

(1.42)

0.24

(1.19)

(8.97)

0.89

(9.46)

0.89

(9.39)

\section{ZIMBABW}

E

$\begin{array}{cc}\mathrm{fli}_{\mathrm{t}} & -0.43 \\ & (-1.72) \\ \mathrm{fli}_{\mathrm{t}-1} & -0.63 \\ & (-2.83) \\ \mathrm{fli}_{\mathrm{t}-2} & -0.38 \\ & (-1.40)\end{array}$

0.64
$(3.02)$
0.65
$(3.09)$
0.64
$(2.79)$

0.24

(0.87)

0.12

(0.44)

0.3

(1.09)

0.2
$(0.87)$
0.16
$(0.67)$
0.02
$(0.22)$

Notes: $\mathrm{t}$ statistics in parenthesis. Private credit denotes the stock of credit to the private sector. 
Table 2: Panel Integration and Cointegration Tests

\section{Part I}
$(\mathrm{s} / \mathrm{y})_{\mathrm{t}} \quad \ln \mathrm{y}_{\mathrm{t}}$
$r_{t}$
fli $_{\mathrm{t}}$
$?_{\mathrm{t}}$
govs $_{t}$

without trend

$\begin{array}{lllllll}\mathrm{P}=0 & -0.617 & 2.623 & -4.152 & 7.165 & -3.495 & -0.141 \\ \mathrm{P}=1 & -0.458 & 1.300 & -3.393 & 5.090 & -3.300 & -0.859\end{array}$

with trend

$\begin{array}{lllllll}\mathrm{P}=0 & 0.027 & 1.213 & -3.707 & 4.676 & -3.517 & -0.589 \\ \mathrm{P}=1 & -1.645 & -0.302 & -4.076 & 3.491 & -3.892 & -2.014\end{array}$

\section{Part II}

cointegrating vector 1: $\left[(s / y)_{t}, \ln y_{t}, r_{t}, f l i_{t}, \pi_{t}\right.$, govs $\left.t\right]$

cointegrating vector 2: $\left[(s / y)_{t}, \ln y_{t}, f l i_{t}\right.$, govs $\left._{t}\right]$

Panel conintegration test ADF t test

(Pedroni)

Panel ADF

(Im, Pesaram, Shin on residuals) cointegrating vector 1 cointegrating vector 2

$-2.74$

$-4.677$

$-4.95$

Notes:

1. P denotes the number of lags in the country specific ADF test.

2. The Panel Integration test is based on Im, Pesaran, Shin (1995). The test is distributed as N $(0,1)$. The unit root hypothesis is rejected at the $5 \%$ significance level for values below -1.645 .

3. The panel ADF t test is based on Pedroni (1997, a b). The test is distributed as $N(0,1)$. 


\section{Table 3: Estimating the Cointegrating Vector for Savings}

Part I: OLS for $(s / y)_{t}=\beta_{o}+\beta_{1} \ln y_{t}+\beta_{2} r_{t}+\beta_{3} f l i_{t}+\beta_{4} \pi_{t}+\beta_{5}$ govs $_{t}+u_{t}$

$\begin{array}{lcccccccc} & \text { CHL } & \text { GHA } & \text { IDN } & \text { KOR } & \text { MYS } & \text { MEX } & \text { TUR } & \text { ZWE } \\ \text { Constant } & -2.084 & -1.120 & -0.859 & -2.491 & -1.186 & -0.890 & 0.450 & -1.828 \\ & (3.209) & (-2.225) & (-1.88) & (-7.658) & (-2.086) & (-3.025) & (0.382) & (-0.912) \\ & & & & & & & & \\ \ln _{\mathrm{t}} & 0.171 & 0.11 & 0.094 & 0.192 & 0.185 & 0.129 & -0.016 & 0.287 \\ & (3.385) & (2.550) & (2.525) & (8.328) & (2.716) & (3.521) & (-0.195) & (1.010) \\ & & & & & & & & \\ \mathrm{r}_{\mathrm{t}} & -0.047 & -0.176 & -0.61 & -0.208 & -0.655 & 0.117 & -0.063 & 0.123 \\ & (-0.740) & (-0.643) & (-4.031) & (-1.232) & (-1.982) & (2.66) & (-1.184) & (0.28) \\ \mathrm{fli}_{\mathrm{t}} & 0.001 & 0.005 & 0.003 & -0.015 & -0.003 & -0.012 & 0.016 & 0.005 \\ & (0.321) & (1.308) & (0.638) & (-2.614) & (-0.473) & (-7.104) & (4.168) & (0.187) \\ & & & & & & & & \\ ?_{\mathrm{t}} & -0.036 & -0.140 & -0.687 & -0.067 & -0.868 & 0.133 & -0.093 & 0.042 \\ & (-0.529) & (-0.540) & (-3.812) & (-0.489) & (-2.446) & (2.422) & (-1.277) & (0.089) \\ & & & & & & & & \\ \text { govs }_{\mathrm{t}} & 0.267 & -0.645 & -1.427 & (-1.080) & -1.321 & -0.579 & (-0.364) & -0.143 \\ & 0.896 & (-3.199) & (-2.670) & (-2.592) & (-7.882) & (-2.351) & (-1.756) & (-0.398) \\ & & & & & & & & \\ \text { NOBS } & 25 & 25 & 24 & 24 & 25 & 25 & 25 & 20\end{array}$




\section{Table 3: Estimating the Cointegrating Vector for Savings}

Part II: Dynamic GLS for $(s / y)_{t}=\beta_{o}+\beta_{1} \ln y_{t}+\beta_{2} r_{t}+\beta_{3} f l i_{t}+\beta_{4} \pi_{t}+\beta_{5}$ govs $_{t}+u_{t}$

$\begin{array}{lcccccccc} & \text { CHL } & \text { GHA } & \text { IDN } & \text { KOR } & \text { MYS } & \text { MEX } & \text { TUR } & \text { ZWE } \\ \text { Constant } & -4.066 & -1.692 & -2.337 & -9.802 & 0.091 & -1.766 & 0.914 & -1.822 \\ & (-3.081) & (-3.121) & (-4.289) & (3.47) & (0.14) & (-4.261) & (0.336) & (-0.525) \\ & & & & & & & & \\ \ln _{\mathrm{t}} & 0.326 & 0.172 & 0.209 & 0.476 & 0.027 & 0.247 & -0.050 & 0.346 \\ & (3.134) & (3.445) & (4.737) & (4.351) & (0.343) & (4.642) & (-0.259) & (0.683) \\ & & & & & & & & \\ \mathrm{r}_{\mathrm{t}} & 0.138 & -1.691 & -0.818 & -0.35 & -0.639 & -0.062 & -0.068 & -1.364 \\ & (1.454) & (-2.217) & (-4.888) & (-1.606) & (-1.710) & (-1.038) & (-0.712) & (-1.338) \\ & & & & & & & & \\ \mathrm{fli}_{\mathrm{t}} & -0.001 & 0.016 & -0.005 & -0.023 & 0.01 & -0.009 & 0.019 & 0.063 \\ & (-0.107) & (2.024) & (-1.035) & (-2.365) & (1.345) & (-3.821) & (2.100) & (0.738) \\ & & & & & & & & \\ ? & 0.152 & -1.203 & -0.684 & -0.383 & -0.791 & 0.100 & -0.087 & -2.107 \\ & (1.585) & (-2.313) & (-3.649) & (-1.641) & (-2.172) & (1.639) & (-0.689) & (-1.450) \\ & & & & & & & & \\ \text { govs }_{\mathrm{t}} & -1.087 & 1.021 & -2.66 & -0.969 & -0.976 & -0.867 & -0.173 & 0.184 \\ & (-2.017) & (1.218) & (-4.200) & (-2.386) & (-4.909) & (3.663) & (0.385) & (0.360)\end{array}$

$\begin{array}{lllllllll}\text { NOBS } & 23 & 23 & 22 & 22 & 23 & 23 & 23 & 18\end{array}$


Table 3: Estimating the Cointegrating Vector for Savings

Part III: Dynamic GLS for $(s / y)_{t}=\beta_{o}+\beta_{1} \ln y_{t}+\beta_{3} f l_{t}+\beta_{5}$ govs $_{t}+u_{t}$

\begin{tabular}{|c|c|c|c|c|c|c|c|c|}
\hline & CHL & GHA & IDN & KOR & MYS & MEX & TUR & ZWE \\
\hline \multirow[t]{2}{*}{ Constant } & -1.701 & -1.747 & -0.335 & -8.083 & -0.227 & -1.877 & 1.362 & -7.497 \\
\hline & $(2.246)$ & $(-4.371)$ & $(-0.354)$ & $(-4.431)$ & $(-0.301)$ & $(-4.096)$ & $(0.827)$ & $(-5.082)$ \\
\hline \multirow[t]{2}{*}{$\ln y_{t}$} & 0.143 & 0.166 & 0.043 & 0.418 & 0.060 & 0.266 & -0.083 & 0.443 \\
\hline & $(2.384)$ & $(4.571)$ & $(0.567)$ & (5.877) & $(0.658)$ & $(4.566)$ & $(-0.716)$ & (6.154) \\
\hline \multirow[t]{2}{*}{$\mathrm{fli}_{\mathrm{t}}$} & 0.003 & 0.003 & 0.003 & -0.02 & 0.004 & -0.01 & 0.015 & -0.027 \\
\hline & $(0.274)$ & $(0.132)$ & $(0.326)$ & $(-2.269)$ & $(0.561)$ & $(-3.544)$ & (3.020) & $(-2.461)$ \\
\hline \multirow[t]{2}{*}{ govs $_{t}$} & -0.206 & -0.463 & -0.719 & -1.000 & -1.014 & -1.297 & -0.180 & -0.989 \\
\hline & $(-0.485)$ & $(-2.329)$ & $(-0.749)$ & $(-2.905)$ & $(-4.634)$ & $(-8.804)$ & $(-0.550)$ & $(-2.844)$ \\
\hline NOBS & 23 & 23 & 22 & 22 & 23 & 23 & 23 & 18 \\
\hline
\end{tabular}

Notes:

1. $\mathrm{t}$-statistics in parenthesis.

2. The dynamic GLS estimates have been obtained by adding the contemporaneous changes of all the RHS variables as additional regressors and by allowing for AR (1) errors. 


\section{Table 4: Error Correction Model for Savings}

\begin{tabular}{|c|c|c|c|c|c|c|c|c|}
\hline & CHL & GHA & IDN & KOR & MYS & MEX & TUR & ZWE \\
\hline Constant & $\begin{array}{c}0.004 \\
(0.537)\end{array}$ & $\begin{array}{c}0.001 \\
(0.225)\end{array}$ & $\begin{array}{c}-0.011 \\
(-2.051)\end{array}$ & $\begin{array}{c}-0.022 \\
(-4.997)\end{array}$ & $\begin{array}{c}-0.011 \\
(-2.352)\end{array}$ & $\begin{array}{c}-0.006 \\
(-1.871)\end{array}$ & $\begin{array}{c}-0.001 \\
(-0.203)\end{array}$ & $\begin{array}{c}0.009 \\
(0.467)\end{array}$ \\
\hline$?(\mathrm{~s} / \mathrm{y})_{\mathrm{t}-1}$ & $\begin{array}{l}-0.082 \\
(-0471)\end{array}$ & $\begin{array}{c}0.072 \\
(0.420)\end{array}$ & $\begin{array}{c}0.149 \\
(1.214)\end{array}$ & $\begin{array}{c}0.110 \\
(1.064)\end{array}$ & $\begin{array}{c}-0.077 \\
(-0.624)\end{array}$ & $\begin{array}{c}0.297 \\
(2.281)\end{array}$ & $\begin{array}{c}0.172 \\
(0.722)\end{array}$ & $\begin{array}{c}-0.023 \\
(-0.068)\end{array}$ \\
\hline$? \ln y_{t}$ & $\begin{array}{c}0.166 \\
(3.216)\end{array}$ & $\begin{array}{c}0.100 \\
(1.432)\end{array}$ & $\begin{array}{c}0.215 \\
(3.269)\end{array}$ & $\begin{array}{c}0.465 \\
(8.747)\end{array}$ & $\begin{array}{c}0.430 \\
(5.463)\end{array}$ & $\begin{array}{c}0.125 \\
(1.886)\end{array}$ & $\begin{array}{c}0.015 \\
(0.176)\end{array}$ & $\begin{array}{c}0.186 \\
(0.681)\end{array}$ \\
\hline$? \mathrm{r}_{\mathrm{t}}$ & $\begin{array}{c}-0.005 \\
(-0.076)\end{array}$ & $\begin{array}{l}-0.336 \\
(0.788)\end{array}$ & $\begin{array}{c}-0.318 \\
(-1.486)\end{array}$ & $\begin{array}{l}-0.128 \\
(1.368)\end{array}$ & $\begin{array}{c}-0.908 \\
(-3.092)\end{array}$ & $\begin{array}{c}0.216 \\
(4.911)\end{array}$ & $\begin{array}{c}0.030 \\
(0.358)\end{array}$ & $\begin{array}{c}-0.263 \\
(-0.533)\end{array}$ \\
\hline$? \mathrm{fli}_{\mathrm{t}}$ & $\begin{array}{c}-0.010 \\
(-0.862)\end{array}$ & $\begin{array}{c}0.011 \\
(1.212)\end{array}$ & $\begin{array}{c}-0.003 \\
0.470\end{array}$ & $\begin{array}{c}-0.013 \\
(-2.388)\end{array}$ & $\begin{array}{c}0.000 \\
(-0.068)\end{array}$ & $\begin{array}{c}0.006 \\
(0.791)\end{array}$ & $\begin{array}{c}0.010 \\
(1.145)\end{array}$ & $\begin{array}{c}-0.014 \\
(-0.436)\end{array}$ \\
\hline$? ?{ }_{\mathrm{t}}$ & $\begin{array}{c}-0.033 \\
(-0.482)\end{array}$ & $\begin{array}{c}-0.279 \\
(-0.824)\end{array}$ & $\begin{array}{c}-0.478 \\
(-2.827)\end{array}$ & $\begin{array}{c}-0.107 \\
(-1.083)\end{array}$ & $\begin{array}{c}-1.360 \\
(-4.429)\end{array}$ & $\begin{array}{c}0.271 \\
(5.417)\end{array}$ & $\begin{array}{c}0.036 \\
(0.386)\end{array}$ & $\begin{array}{c}-0.371 \\
(-0.749)\end{array}$ \\
\hline ? govs $_{\mathrm{t}}$ & $\begin{array}{c}0.146 \\
-0.586\end{array}$ & $\begin{array}{c}-0.745 \\
(-3.104)\end{array}$ & $\begin{array}{c}-0.983 \\
(-2.332)\end{array}$ & $\begin{array}{l}-1.297 \\
(-6.897)\end{array}$ & $\begin{array}{c}-1.319 \\
(-9.548)\end{array}$ & $\begin{array}{c}-0.159 \\
(-8.885)\end{array}$ & $\begin{array}{c}-0.239 \\
(-0.847)\end{array}$ & $\begin{array}{c}-0.091 \\
(-0.304)\end{array}$ \\
\hline$e c_{t-1}$ & $\begin{array}{c}-0.344 \\
(-1.612)\end{array}$ & $\begin{array}{c}-1.071 \\
(-3.473)\end{array}$ & $\begin{array}{c}-0.890 \\
(-4.893)\end{array}$ & $\begin{array}{c}-0.429 \\
(-3.078)\end{array}$ & $\begin{array}{c}-0.856 \\
(-3.398)\end{array}$ & $\begin{array}{c}-0.779 \\
(-3.644)\end{array}$ & $\begin{array}{c}-0.697 \\
(-2.485)\end{array}$ & $\begin{array}{c}-0.274 \\
(-0.806)\end{array}$ \\
\hline $\mathrm{R} 2$ & 0.500 & 0.583 & 0.730 & 0.872 & 0.864 & 0.897 & 0.176 & 0.000 \\
\hline BG test & 0.088 & 0.085 & 0.179 & 0.167 & 0.57 & 0.126 & 0.619 & 0.025 \\
\hline JOBS & 23 & 23 & 22 & 22 & 23 & 23 & 23 & 18 \\
\hline
\end{tabular}

Notes:

1. t-statistics in parenthesis.

2. BG denotes the marginal significance level for the Breusch-Godfrey test for serial correlation up to the second order. 


\section{Table 5: Restricted SURE Estimates}

\begin{tabular}{|c|c|c|}
\hline & (1) & (2) \\
\hline \multirow[t]{2}{*}{$\ln y_{t}$} & 0.120 & 0.207 \\
\hline & (16.93) & (14.13) \\
\hline \multirow[t]{2}{*}{$r_{t}$} & 0.061 & 0.101 \\
\hline & $(3.42)$ & $(3.62)$ \\
\hline \multirow[t]{2}{*}{$\mathrm{fli}_{\mathrm{t}}$} & -0.003 & -0.010 \\
\hline & $(-3.125)$ & $(-8.440)$ \\
\hline \multirow[t]{2}{*}{$?_{\mathrm{t}}$} & 0.065 & 0.168 \\
\hline & (3.498) & (10.696) \\
\hline \multirow[t]{2}{*}{ govs $_{t}$} & -0.745 & -0.660 \\
\hline & $(-14.425)$ & $(-16.446)$ \\
\hline NOBS & 160 & 144 \\
\hline LR & 0.000 & 0.000 \\
\hline
\end{tabular}

Notes:

1. t-statistics in parenthesis.

2. LR denotes the marginal significance level of the likelihood ratio test on the equality across countries of the long run coefficients. 
Table 6: Cointegrating Vector for Savings Adjusting for Domestic Capital Gains

Part I: OLS for $(s / y)_{t}^{a}=\beta_{0}+\beta_{1} \ln y_{t}^{a}+\beta_{2} r_{t}+\beta_{3} f l i_{t}+\beta_{4} \pi_{t}+\beta_{5} g o v s_{t}^{a}+u_{t}$

$\begin{array}{lcccccccc} & \text { CHL } & \text { GHA } & \text { IDN } & \text { KOR } & \text { MYS } & \text { MEX } & \text { TUR } & \text { ZWE } \\ \text { Constant } & -2.109 & -1.539 & -0.77 & -2.438 & -0.294 & -0.631 & 0.097 & -1.819 \\ & (-3.946) & (-3.015) & (-1.960) & (-7.682) & (-0.518) & (-2.821) & (0.085) & (-0.705) \\ & & & & & & & & \\ \text { ln } \mathrm{y}_{\mathrm{t}} & 0.173 & 0.148 & 0.087 & 0.188 & 0.077 & 0.103 & 0.008 & 0.283 \\ & (4.174) & (3.363) & (2.734) & (8.441) & (1.131) & (3.586) & (0.097) & (0.757) \\ & & & & & & & & \\ \mathrm{r}_{\mathrm{t}} & 0.000 & -0.195 & -0.619 & -0.225 & -0.927 & 0.093 & -0.058 & 0.203 \\ & (0.007) & (-0.747) & (-4.009) & (-1.342) & (-2.644) & (2.741) & (-1.071) & (0.421) \\ & & & & & & & & \\ \mathrm{fli}_{\mathrm{t}} & 0.000 & 0.005 & 0.004 & (0.016) & 0.005 & (0.009) & 0.017 & (0.009) \\ & (0.085) & (1.246) & (0.962) & (-2.591) & (0.806) & (-4.862) & (4.014) & (-0.123) \\ & & & & & & & & \\ ? & -0.038 & -0.186 & -0.700 & -0.075 & -1.031 & 0.140 & -0.151 & 0.033 \\ & (-0.679) & (-0.717) & (-3.788) & (-0.548) & (-2.583) & (3.281) & (-2.155) & (0.058) \\ & & & & & & & & \\ \text { govs }_{\mathrm{t}} & 0.059 & -0.425 & -1.356 & -0.432 & -1.005 & -0.792 & -0.274 & -0.029 \\ & -0.331 & (-1.539) & (-2.906) & (-2.406) & (-6.370) & (-5.623) & (-1.105) & (-0.057) \\ & & & & & & & & \\ \text { NOBS }^{*} & 25 & 23 & 24 & 24 & 25 & 24 & 25 & 17\end{array}$


Table 6: Cointegrating Vector for Savings Adjusting for Domestic Capital Gains

Part II: Dynamic GLS for $(s / y)_{t}^{a}=\beta_{0}+\beta_{1} \ln y_{t}^{a}+\beta_{2} r_{t}+\beta_{3} f l i_{t}+\beta_{4} \pi_{t}+\beta_{5}$ govs $_{t}^{a}+u_{t}$

\begin{tabular}{|c|c|c|c|c|c|c|c|c|}
\hline & CHL & GHA & IDN & KOR & MYS & MEX & TUR & ZWE \\
\hline Constant & $\begin{array}{c}-2.202 \\
(-1.931)\end{array}$ & $\begin{array}{c}-1.329 \\
(-2.751)\end{array}$ & $\begin{array}{c}-2.205 \\
(-4.528)\end{array}$ & $\begin{array}{c}-9.827 \\
(-3.145)\end{array}$ & $\begin{array}{c}0.906 \\
(1.330)\end{array}$ & $\begin{array}{c}-0.728 \\
(-3.248)\end{array}$ & $\begin{array}{c}2.461 \\
(1.023)\end{array}$ & $\begin{array}{c}-3.902 \\
(-1.243)\end{array}$ \\
\hline $\ln y_{t}$ & $\begin{array}{c}0.178 \\
(1.966)\end{array}$ & $\begin{array}{c}0.135 \\
(3.176)\end{array}$ & $\begin{array}{c}0.197 \\
(5.057)\end{array}$ & $\begin{array}{c}0.473 \\
(3.936)\end{array}$ & $\begin{array}{c}-0.069 \\
(-0.836)\end{array}$ & $\begin{array}{c}0.113 \\
(3.947)\end{array}$ & $\begin{array}{c}-0.162 \\
(-0.939)\end{array}$ & $\begin{array}{c}0.684 \\
(1.476)\end{array}$ \\
\hline$r_{t}$ & $\begin{array}{c}0.045 \\
(0.062)\end{array}$ & $\begin{array}{c}-0.534 \\
(-1.505)\end{array}$ & $\begin{array}{c}-0.834 \\
(-5.018)\end{array}$ & $\begin{array}{c}-0.349 \\
(-1.517)\end{array}$ & $\begin{array}{c}-1.143 \\
(-3.131)\end{array}$ & $\begin{array}{c}0.004 \\
(0.053)\end{array}$ & $\begin{array}{c}-0.059 \\
(-0.751)\end{array}$ & $\begin{array}{c}-3.724 \\
(-3.384)\end{array}$ \\
\hline $\mathrm{fli}_{\mathrm{t}}$ & $\begin{array}{c}0.008 \\
(0.434)\end{array}$ & $\begin{array}{c}0.006 \\
(1.207)\end{array}$ & $\begin{array}{l}(0.003) \\
(-0.805)\end{array}$ & $\begin{array}{l}(0.023) \\
(-2.269)\end{array}$ & $\begin{array}{c}0.016 \\
(2.111)\end{array}$ & $\begin{array}{l}(0.005) \\
(-1.822)\end{array}$ & $\begin{array}{c}0.025 \\
(3.221)\end{array}$ & $\begin{array}{c}0.277 \\
(3.199)\end{array}$ \\
\hline$?_{\mathrm{t}}$ & $\begin{array}{c}0.047 \\
(0.585)\end{array}$ & $\begin{array}{c}-0.606 \\
(-1.842)\end{array}$ & $\begin{array}{c}-0.679 \\
(-3.628)\end{array}$ & $\begin{array}{c}-0.385 \\
(-1.561)\end{array}$ & $\begin{array}{c}-1.256 \\
(-3.503)\end{array}$ & $\begin{array}{c}0.245 \\
(4.648)\end{array}$ & $\begin{array}{c}-0.180 \\
(-1.748)\end{array}$ & $\begin{array}{c}-4.983 \\
(-3.456)\end{array}$ \\
\hline govs $_{t}$ & $\begin{array}{c}-0.246 \\
(-0.699)\end{array}$ & $\begin{array}{c}0.179 \\
(0.323)\end{array}$ & $\begin{array}{c}-2.003 \\
(-4.516)\end{array}$ & $\begin{array}{c}-0.885 \\
(-2.182)\end{array}$ & $\begin{array}{c}-0.685 \\
(-3.463)\end{array}$ & $\begin{array}{c}-0.998 \\
(-6.241)\end{array}$ & $\begin{array}{c}0.147 \\
(0.336)\end{array}$ & $\begin{array}{c}-1.777 \\
(-2.246)\end{array}$ \\
\hline NOBS & 23 & 21 & 22 & 22 & 23 & 22 & 23 & 15 \\
\hline
\end{tabular}

Notes:

1. t-statistics in parenthesis.

2. $(\mathrm{s} / \mathrm{y})_{\mathrm{t}}^{\mathrm{a}}, \ln \mathrm{y}_{\mathrm{t}}^{\mathrm{a}}$, govs ${ }_{\mathrm{t}}^{\mathrm{a}}$ have been adjusted for capital gains (losses) on nominally denominated domestic assets due to inflation. 
Table 7: Excess Sensitivity Tests and the Augmented Euler Equation for Consumption (GMM Estimates)

\begin{tabular}{lcccccccc}
\multicolumn{1}{l}{ CHL } & GHA & IDN & KOR & MYS & MEX & TUR & ZWE \\
$?$ ? ln $\mathrm{y}_{\mathrm{t}}$ & 0.550 & 1.705 & 1.606 & 0.359 & 1.185 & 0.687 & 0.575 & 1.088 \\
& $(3.222)$ & $(1.056)$ & $(1.113)$ & $(2.089)$ & $(2.593)$ & $(3.127)$ & $(1.445)$ & $(3.392)$ \\
& & & & & & & & \\
$\mathrm{r}_{\mathrm{t}}$ & 0.076 & 0.349 & 0.490 & 0.275 & 0.767 & 0.181 & 0.028 & 0.280 \\
& $(2.464)$ & $(-0.828)$ & $(0.955)$ & $(1.412)$ & $(1.056)$ & $(2.688)$ & $(0.233)$ & $(-0.837)$ \\
BG test & 0.653 & 0.041 & 0.870 & 0.424 & 0.042 & 0.041 & 0.634 & 0.491 \\
NOBS & 24 & 24 & 23 & 23 & 24 & 24 & 24 & 19
\end{tabular}

Part II

\begin{tabular}{|c|c|c|c|c|c|c|c|c|}
\hline \multirow{3}{*}{$\mathrm{a}$} & CHL & GHA & IDN & KOR & MYS & MEX & TUR & \multirow[t]{3}{*}{ ZWE } \\
\hline & -0.81 & & -7.566 & -2.673 & 6.683 & -0.136 & -4.811 & \\
\hline & $(-2.914)$ & & $(-1.454)$ & $(-0.462)$ & $(0.30)$ & $(-0.016)$ & 11) & \\
\hline \multirow[t]{2}{*}{$a_{1}$} & -0.109 & & 0.272 & -1.813 & -1.42 & 0.701 & 0.731 & \\
\hline & $(-0.735)$ & & $(0.90)$ & $(-0.733)$ & $(-0.591)$ & $(0.49)$ & $(2.36)$ & \\
\hline \multirow[t]{2}{*}{$\mu$} & 0.771 & & 0.841 & 0.540 & 0.570 & 0.560 & 1.471 & \\
\hline & (2.668) & & $(2.241)$ & (91.844) & (18.943) & $(2.791)$ & $(34.736)$ & \\
\hline \multirow[t]{2}{*}{$\mathrm{s}$} & -0.001 & & 1.066 & 6.278 & 1.055 & 0.449 & 0.477 & \\
\hline & $(-0.013)$ & & (1.111) & $(0.163)$ & $(1.255)$ & (1.728) & $(0.472)$ & \\
\hline OR test & 0.057 & & 0.880 & 0.931 & 0.079 & 0.655 & 0.916 & \\
\hline NOBS & 24 & & 23 & 23 & 24 & 24 & 24 & \\
\hline
\end{tabular}

Notes:

1. t-statistics in parenthesis.

2. The instruments used are

3. BG denotes the marginal significance level for the Breusche-Godfrey test for serial correlation up to the second order. 
3. OR denotes the marginal significance level of the test of over-identifying restrictions. 
Figure 1: CHILE

(a)

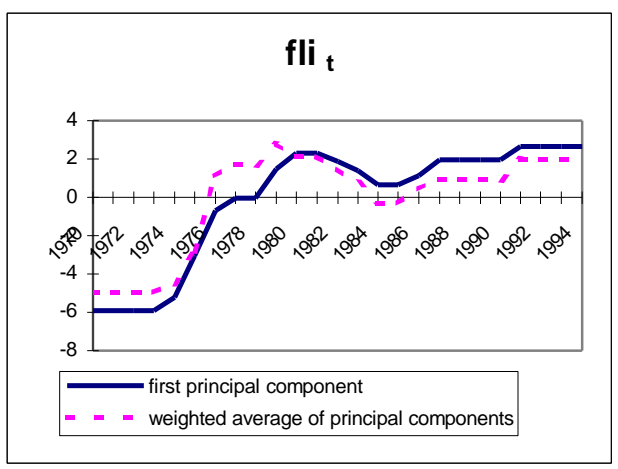

(c)

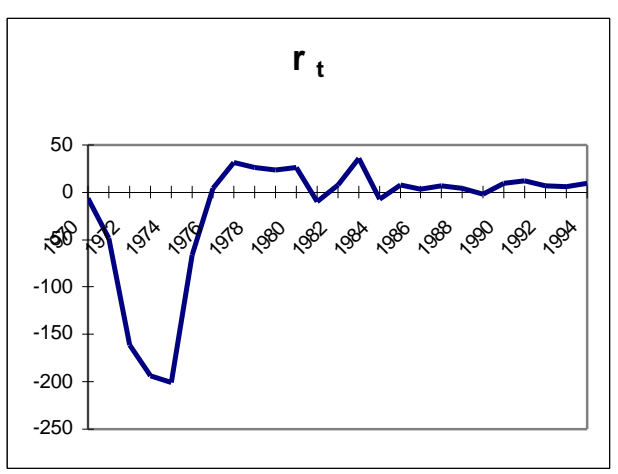

(b)

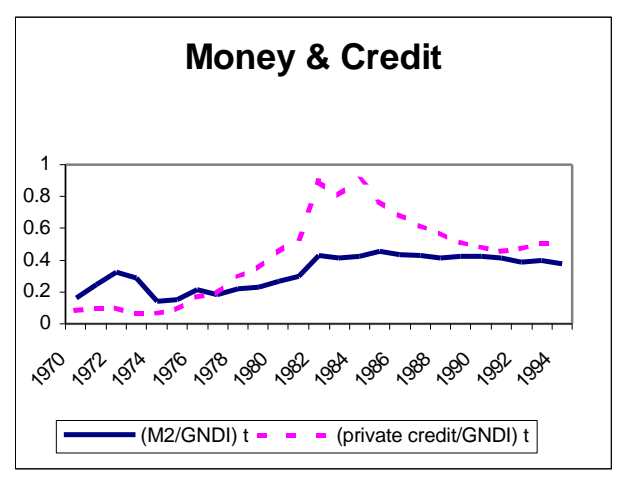

(d)

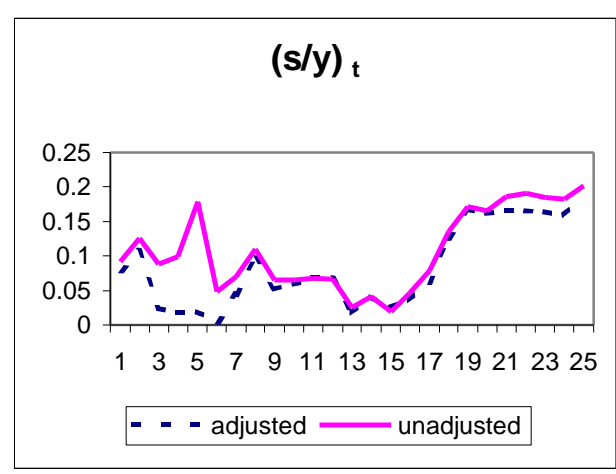


Figure 1: CHILE

(a)

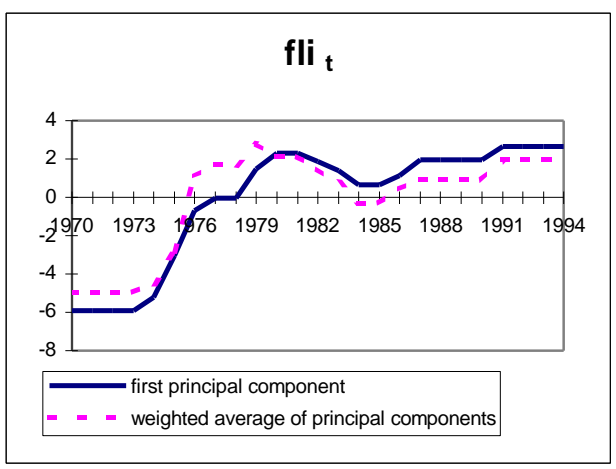

(c)



(b)

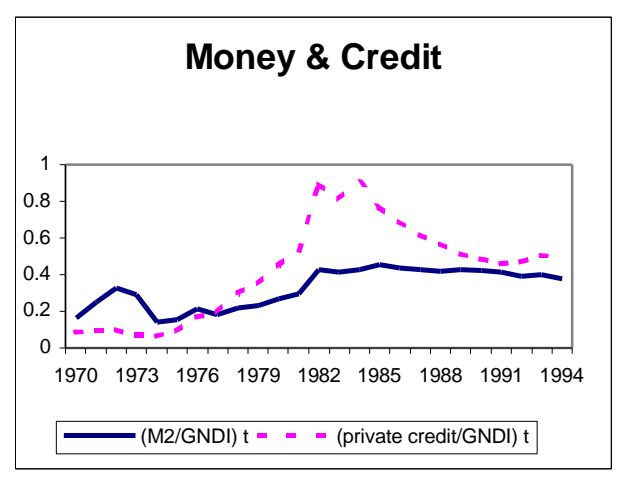

(d)

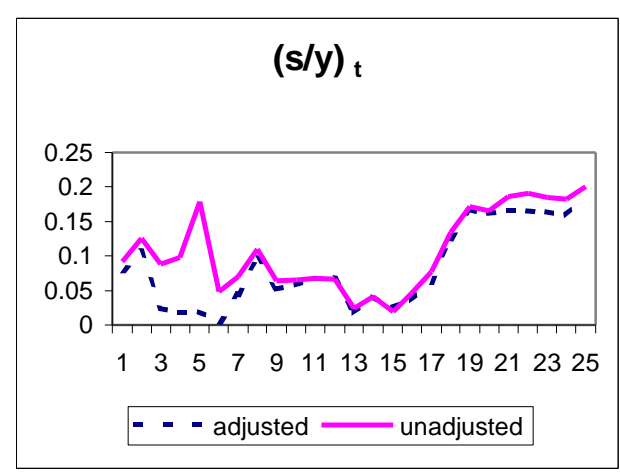


Figure 2: GHANA

(a)

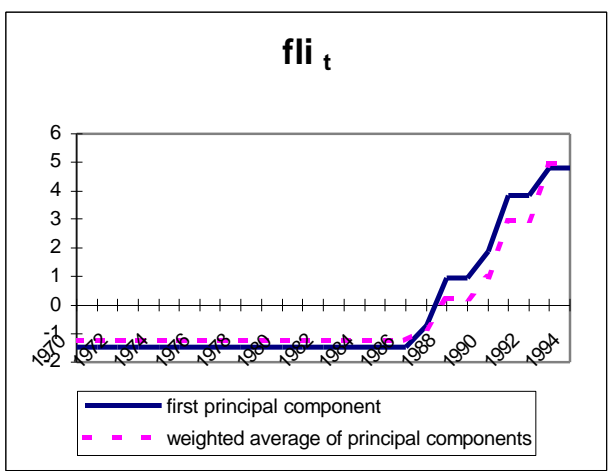

(c)

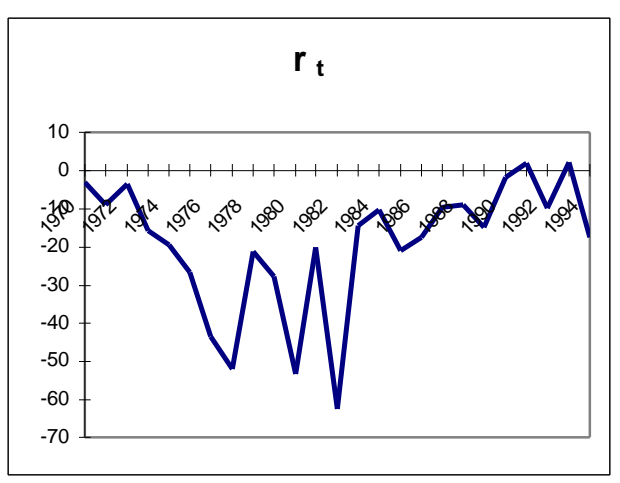

(b)

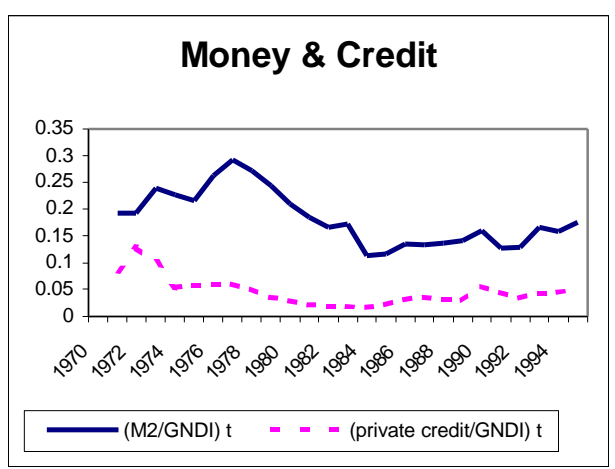

(d)

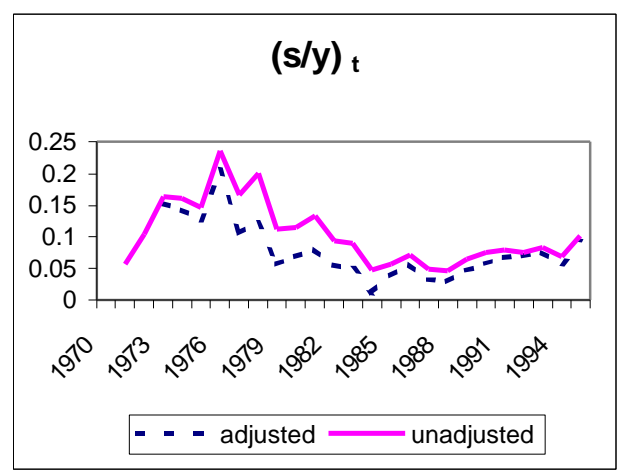


Figure 3: INDONESIA

( a )

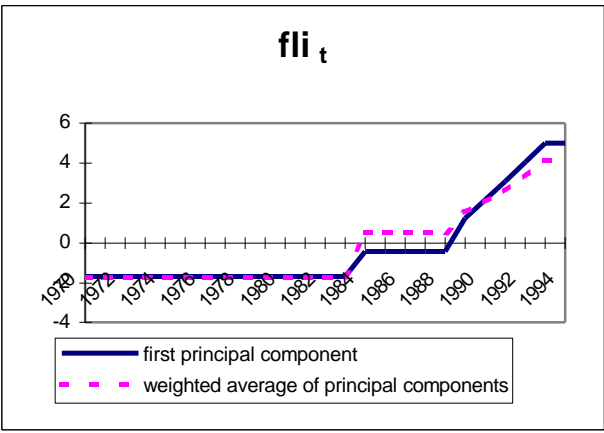

(c)

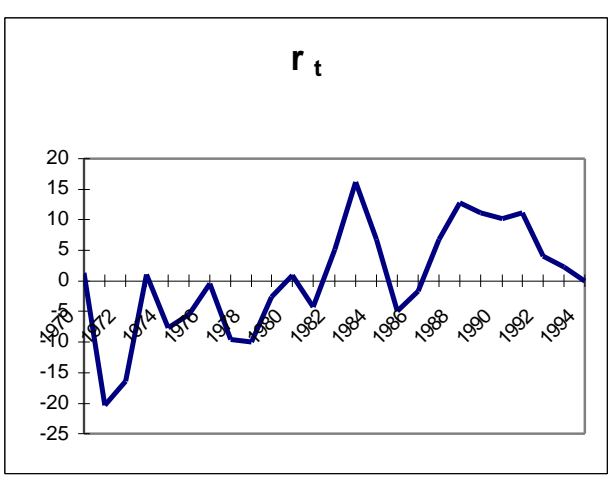

(b)

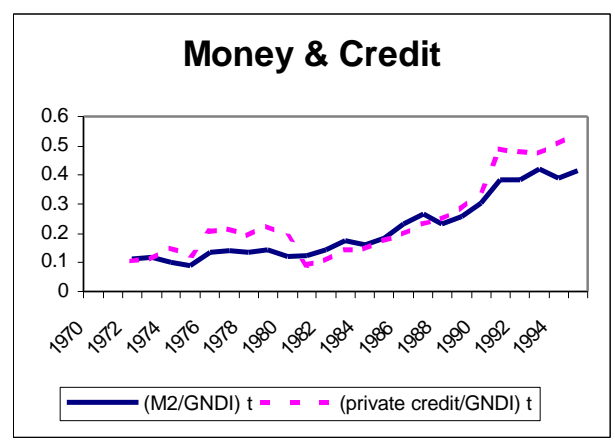

(d)

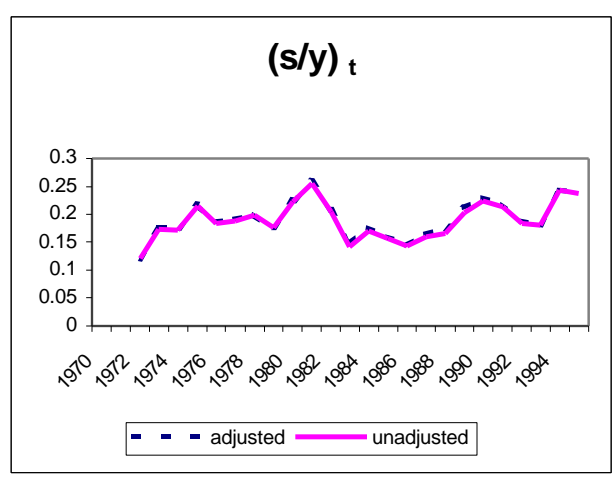


Figure 5: MALAYSIA

( a )

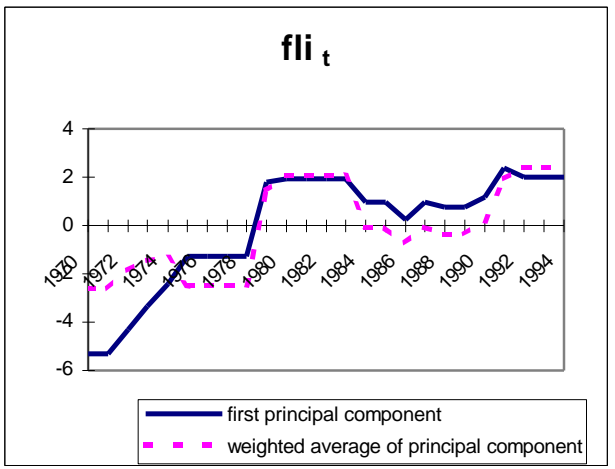

(c)

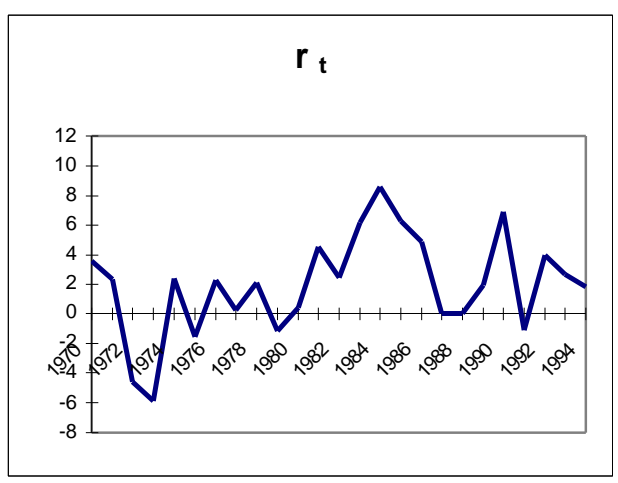

(b)



(d)

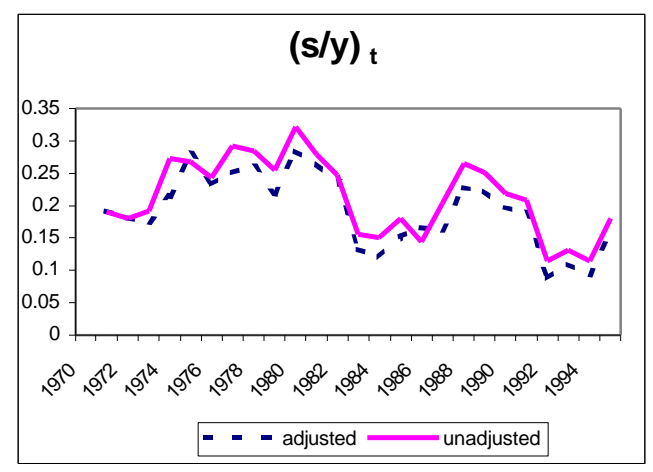


Figure 6: MEXICO

(a)

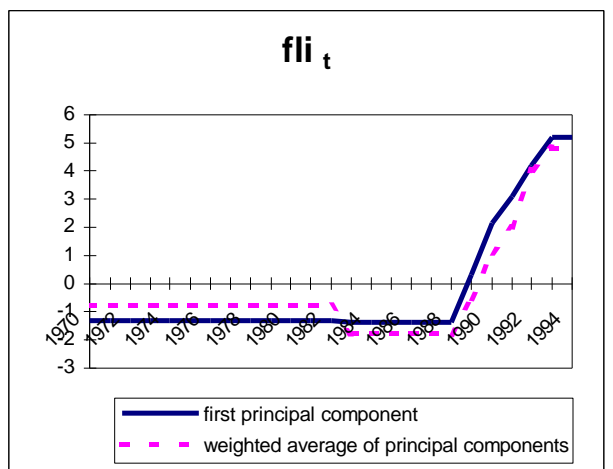

(c)

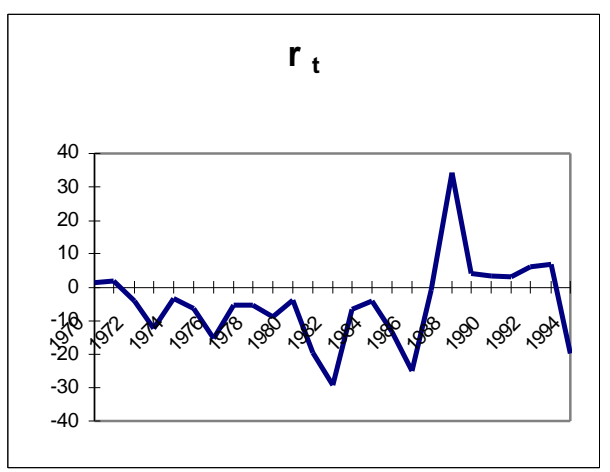

(b)



(d)

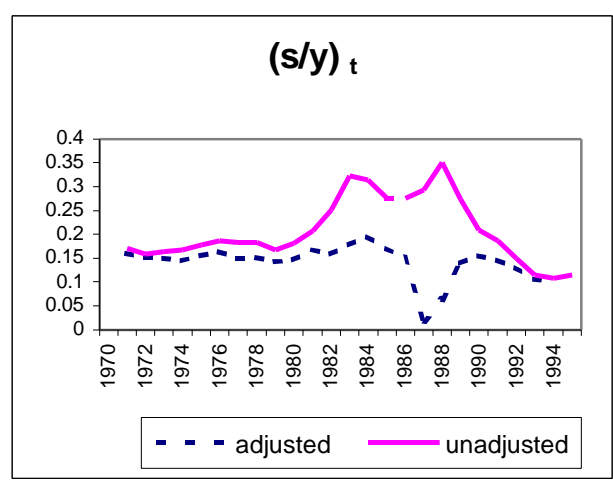


Figure 7: TURKEY

(a)

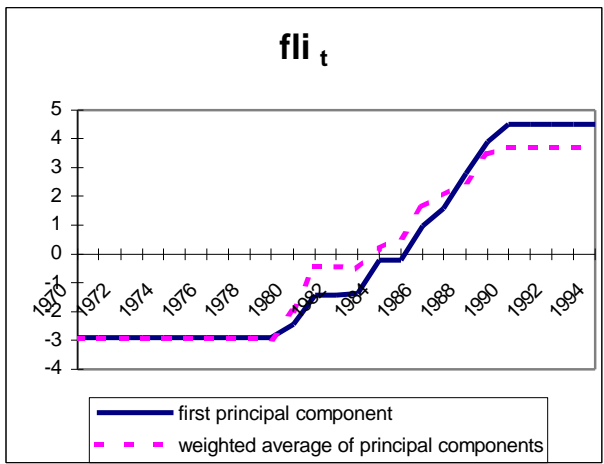

(c)

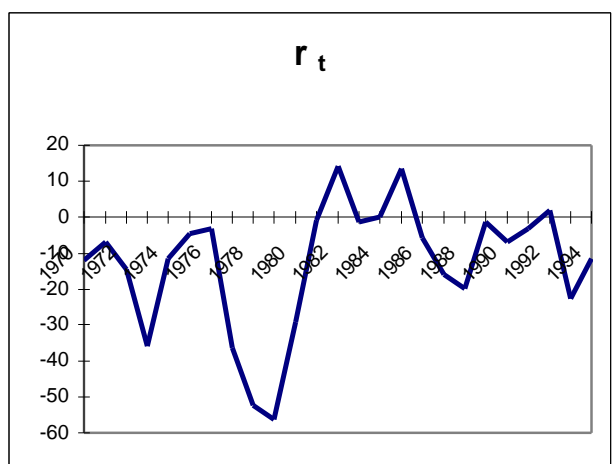

(b)

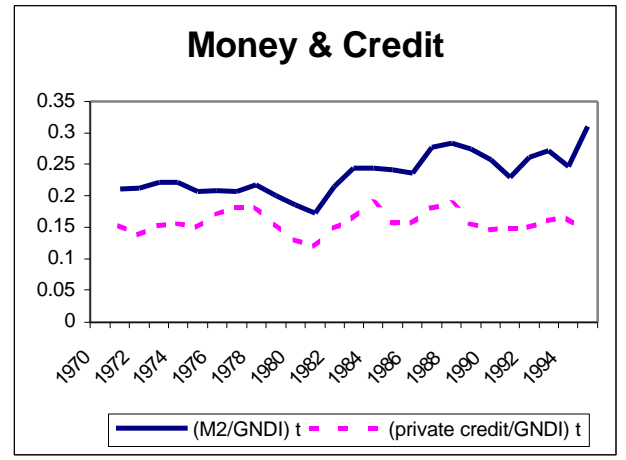

(d)

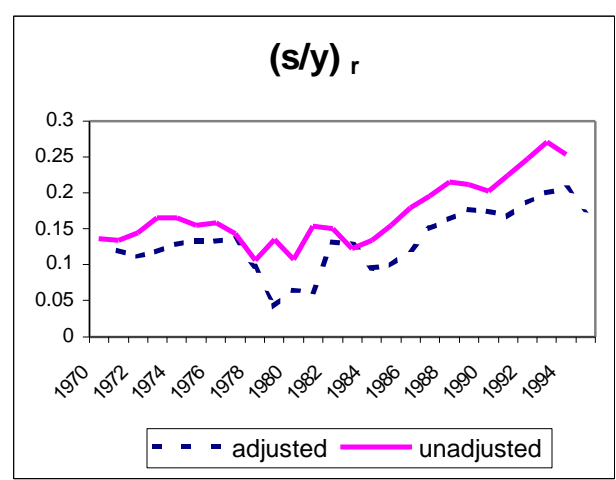


Figure 8: ZIMBABWE

(a)

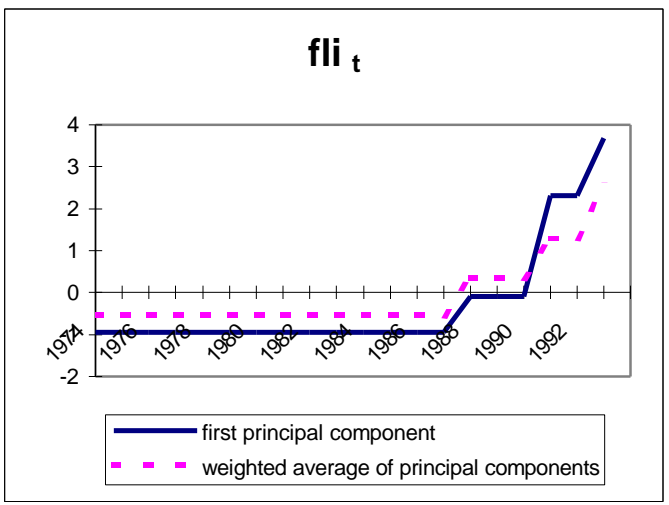

(c)

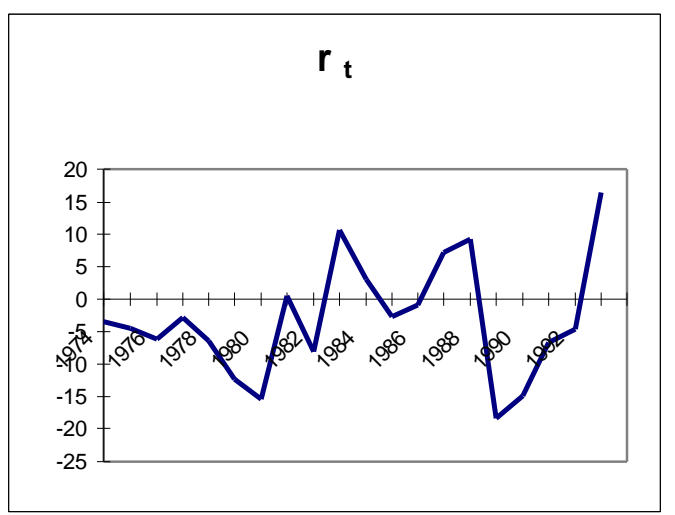

(b)

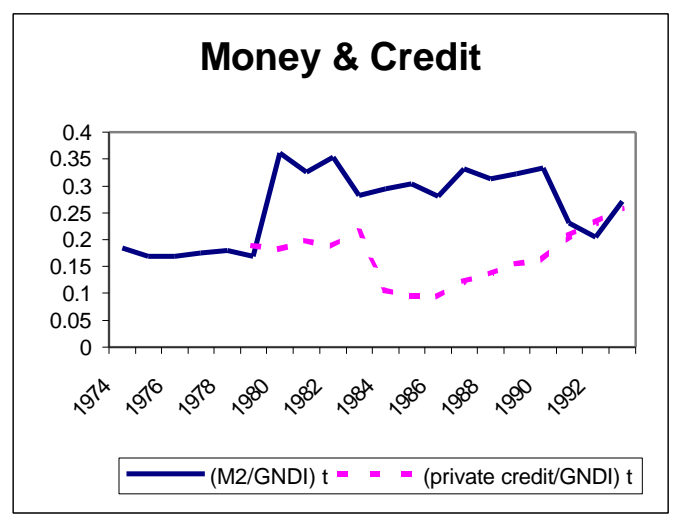

(d)




